\title{
Systematics and phylogeny of the Brassicaceae (Cruciferae): an overview
}

\author{
I. A. Al-Shehbaz ${ }^{1}$, M. A. Beilstein ${ }^{2}$, and E. A. Kellogg ${ }^{2}$ \\ ${ }^{1}$ Missouri Botanical Garden, St. Louis, Missouri, USA \\ ${ }^{2}$ Department of Biology, University of Missouri-St. Louis, St. Louis, Missouri, USA
}

Received November 9, 2005; accepted December 13, 2005

Published online: June 19, 2006

(c) Springer-Verlag 2006

\begin{abstract}
A critical review of characters used in the systematics of the Brassicaceae is given, and aspects of the origin, classification, and generic delimitation of the family discussed. Molecular phylogenetic studies of the family were reviewed, and major clades identified. Based on molecular studies, especially from the $n d h \mathrm{~F}$ chloroplast gene, and careful evaluation of morphology and generic circumscriptions, a new tribal alignment of the Brassicaceae is proposed. In all, 25 tribes are recognized, of which seven (Aethionemeae, Boechereae, Descurainieae, Eutremeae, Halimolobeae, Noccaeeae, and Smelowskieae) are described as new. For each tribe, the center(s) of distribution, morphology, and number of taxa are given. Of the 338 genera currently recognized in the Brassicaceae, about 260 genera (or about $77 \%$ ) were either assigned or tentatively assigned to the 25 tribes. Some problems relating to various genera and tribes are discussed, and future research developments are briefly covered.
\end{abstract}

Key words: Brassicaceae, characters, origin, classification, generic circumscription, molecular data, major clades, new tribal alignments.

The Brassicaceae (Cruciferae), or mustard family, is a monophyletic group of about 338 genera and some 3709 species distributed worldwide. It includes many economically important ornamental and crop species (veg- etables or sources of industrial and cooking oils, forage, and condiments), but is perhaps best known for thale cress, Arabidopsis thaliana (L.) Heynh., the model organism of flowering plants. The latter species is currently used in almost every discipline of experimental biology and its completely sequenced genome (The Arabidopsis Genome Initiative, 2000) paved the way to a better understanding of every aspect of plant biology.

The morphological diversity, systems of classification, earlier literature, endemism, and distribution of the family are discussed in Hedge (1976), Al-Shehbaz (1984), and Appel and Al-Shehbaz (2003). These aspects will not be repeated here, and the interested reader should consult those works and the references cited therein. For extensive reviews on the molecular phylogenetic studies of the family, Koch (2003), Koch et al. (2003a), MitchellOlds et al. (2005), and Beilstein et al. (2006) should be checked.

The present paper addresses the following major aspects of the family: the evaluation of characters and their utilization in infrafamilial classifications, delimitation of genera, molecular data and major subdivisions of the family, 
problematic taxa, and future challenges of research.

\section{Characters}

Numerous studies (e.g. Al-Shehbaz 1984, Price et al. 1994, Appel and Al-Shehbaz 2003, Koch et al. 2003a, Mitchell-Olds et al. 2005) have amply demonstrated that morphological characters in the Brassicaceae are highly homoplasious, making it virtually impossible to utilize them alone in establishing phylogenetic relationships on a family-wide basis or sometimes even within genera (Mummenhoff et al. 1997a). The lack of a robust phylogeny of the family led some recent authors (e.g. Rollins 1993, Appel and Al-Shehbaz 2003) to adopt an alphabetical system in their enumeration of taxa.

Fruit morphology and seed embryo type (position of the radicle in relation to cotyledons) have been used almost exclusively in the delimitation of taxa at all taxonomic levels, but particularly at generic and tribal ranks, while floral, vegetative, and trichome characters have often been considered far less significant. However, as shown below, fruit and embryo features can be subject to considerable convergence and therefore are sometimes taxonomically unreliable. For example, diplecolobal cotyledons (i.e. with incumbent cotyledons folded two or more times), thought to be unique to the tribe Heliophileae (Schulz 1936), evolved independently in Lepidium L. s.1. (Hewson 1981, Mummenhoff et al. 2001a). From that type, spiral cotyledons probably evolved in Brachycarpaea DC. (Appel and AlShehbaz 1997, Mummenhoff et al. 2005), a genus recently reduced to synonymy of Heliophila L. (Al-Shehbaz and Mummenhoff 2005). Incumbent and accumbent cotyledons, the most common cotyledonary types in the family, are the least reliable because they occur within numerous genera, including Arabidopsis (DC.) Heynh. and Erysimum L. Unfortunately, little is known about the genetic control of cotyledonary position, and A. thaliana would be the ideal species to study the evolution of this character.
Although the Brassicaceae was once thought to be exclusively stenopalynous (i.e. with uniform pollen) with only tricolpate pollen (Erdtman 1971), preliminary surveys (e.g. Rollins and Banerjee 1979) demonstrated the existence in the New World of several genera with 4-11-colpate pollen. This group with "polycolpate" pollen has subsequently been shown by O'Kane and Al-Shehbaz (2003) to form a monophyletic clade. However, a more comprehensive palynological survey of the family is needed to determine the utility of pollen in taxonomic and phylogenetic studies. In fact, pollen data were shown to be useful in the separation of putatively closely related genera (Rollins 1979, Al-Shehbaz 1989).

Despite the conservative floral architecture of the family, there can be enormous variation among related groups or even within genera. For example, Lepidium, Heliophila, Alyssum L., and Streptanthus Nutt. all exhibit tremendous floral diversity that is quite useful in defining lineages and assessing relationships (Mummenhoff et al. 2001a, 2005). Many other genera (e.g. Stenopetalum R.Br., Schizopetalon Sims, Ornithocarpa Rose, Stanleya Nutt., Warea Nutt., Iberis L., to name a few) are readily recognized by their flowers and evidently are monophyletic. However, little attention has been given to the value of floral morphology in establishing monophyletic groups in the vast majority of the family.

Finally, trichome morphology, first emphasized by Prantl (1891) but utilized only a little in subsequent studies (e.g. Rollins and Banerjee 1975, 1976), appears to be far more useful in the separation of closely related genera (e.g. Al-Shehbaz et al. 1999) and holds significant promise in the delimitation of monophyletic groups. Although both simple and branched trichomes can be found in most major clades of the family (Beilstein et al. 2006, Bailey pers. com.), the trichome subtypes can be far more valuable. The extensive studies on trichome development in Arabidopsis thaliana (e.g. Schwab et al. 2000, Hülskamp 2000, Szymanski et al. 2000, Beilstein and Szymanski 2004) have identified a significant number 
of genes (e.g. ANGUSTIFOLIA, STICHEL, ZWICHEL) responsible for the genetic pathways that control trichome morphology. However, sequence comparisons from such genes are not available for other genera of the family. It is not yet known if sequence data from such genes are useful in phylogenetic studies in the family.

\section{Origin and classification}

Hayek (1911), followed by Schulz (1936) and Janchen (1942), provided the first theory on the origin of the Brassicaceae. They believed in a New World origin of the family from the capparaceous subfamily Cleomoideae through the "basal" mustard tribe Theylopodieae (Stanleyeae). Views of this German school were followed by Al-Shehbaz (1973, 1985a), Hauser and Crovello (1982), and Takhtajan (1997). Indeed, Nuttall (1834) proposed the name Stanleyeae as a distinct family intermediate between the Capparaceae and Cruciferae. It included Stanleya Nutt. and Warea Nutt. By contrast, Dvorák (1973) proposed an Old World origin from the Cleomaceae via the tribe Hesperideae, but his views were not subsequently followed.

Molecular studies (Hall et al. 2002, Koch et al. 2003a and references therein, MitchellOlds et al. 2005, Beilstein et al. 2006) have clearly demonstrated that the Brassicaceae evolved in the Old World and is sister to the Cleomaceae, that Aethionema R.Br. is the most "basal" genus in the family, that the Thelypodieae (hereafter Schizopetaleae; see below) is rather advanced, and that the remarkable superficial floral and fruit similarities (e.g. exserted stamens equal in length, linear anthers coiled at dehiscence, dense racemes, linear fruits, sessile stigmas, long gynophores) between members of this tribe, especially Stanleya and Warea (first discovered species of each was originally described as Cleome L.) and the Cleomaceae evolved through convergence. A closer comparison of Aethionema with some members of the Cleomaceae is given in the section on major clades of the family.
Although Schulz's (1936) classification of the Brassicaceae has been modified and criticized (e.g. Janchen 1942; Al-Shehbaz 1973, 1984), it continued to be the most widely used to the present. However, all of his new suprageneric taxa that first appeared in that work are invalidly published (see Greuter et al. 2000). Regardless of the number of infrafamilial taxa recognized, his and the earlier systems of Prantl (1891) and Hayek (1911) utilized a limited number of characters, many of which have recently been shown to be subject to convergence. As a result, almost all of their major subdivisions of the family have been shown by molecular studies to be polyphyletic and artificial (Price et al. 1994; Warwick and Black 1994, 1997a, 1997b; Koch et al. 1999a, 2000, 2001, 2003a; Zunk et al. 1999; Bailey et al. 2002; O'Kane and Al-Shehbaz 2003; Mitchell-Olds et al. 2005; Warwick and Sauder 2005; Beilstein et al. 2006). A classic example of the artificiality of previous classifications is illustrated by Arabidopsis, Capsella Medik., Neslia Desv., and Arabis pendula L. (now Catolobus (C. A. Mey.) Al-Shehbaz). Schulz (1936) placed these taxa in the tribes Sisymbrieae, Lepidieae, Euclidieae, and Arabideae, respectively, but molecular data (Koch et al. 2001, O'Kane and Al-Shehbaz 2003, Beilstein et al. 2006) clearly demonstrated that the four genera are very closely related and therefore should be placed in the same tribe/clade (see below).

\section{Generic delimitations}

There is a considerable lack of agreement among authors of the past century regarding the number of genera in the family (Table 1). Of those currently recognized, 225 genera (66\% of the total) are either monotypic or oligotypic (with 2-4 spp.). The vast majority of these monotypic and oligotypic genera are nested within, and should be united with, the larger ones (see below).

Comparative sequence data of rapidly evolving DNA regions of the chloroplast (e.g. $n d h \mathrm{~F}$ gene) and nucleus (e.g. ITS) 
Table 1. Enumeration of genera recognized by various authors

\begin{tabular}{lcclll}
\hline & Hayek & Schulz & Authors & Appel and Al-Shehbaz & Warwick et al. \\
& {$[1911]$} & {$[1936]$} & To [1984] & {$[2003]$} & {$[2006]$} \\
\hline Total genera & 231 & 351 & 369 & 337 & 338 \\
Synonyms & 11 & 21 & 88 & 59 & 20 \\
Added genera & 34 & 141 & 106 & 27 & 21 \\
\hline
\end{tabular}

indicate that many taxa show remarkable sequence similarities but drastically different fruit morphologies and embryo positions (Warwick and Black 1994; Crespo et al. 2000; Beilstein et al. 2006; Mummenhoff et al. 2001a, 2005). Such data suggest that major changes in fruit morphology can occur rather rapidly and independent of other characters. As shown in Arabidopsis (see below), a relatively small number of genes are responsible for significant alterations in fruit shape, and it is quite likely that the same holds for the rest of the family. Therefore, drastic bursts of fruit evolution can rapidly take place that are independent of molecular markers or other aspects of morphology. In cases like these, differences in fruit morphology would result in erroneous classifications or generic delimitations and would obscure phylogenetic relationships.

Fruit development in Arabidopsis thaliana has been reasonably well studied, and a few genes (e.g. FRUITFUL, MADS-box, SHATTERPROOF) are known to alter fruit shape (i.e. length/width ratio; silique vs. silicle) and dehiscence (Ferrandiz et al. 1999, 2000; Ferrandiz 2002; Dinneny and Yanofsky 2004). At least six genes have been identified that control fruit dehiscence in this species, and as few as one or double mutant genes can be the difference between dehiscent and indehiscent fruits (Liljegren et al. 2000, 2004; Dinneny and Yanofsky 2004; Polster 2005). These findings should caution the use of fruit dehiscence vs. indehiscence as the main criterion for the delimitation of genera. In fact, the only difference that distinguished Cardaria Desv. from Lepidium and Boleum Desv. from Vella
L. is having dehiscent instead of indehiscent fruits. Cardaria is nested within Lepidium (Mummenhoff 1995, Mummenhoff et al. 2001a) and Boleum within Vella (Warwick and Black 1994, Crespo et al. 2000). Therefore, the reduction of Cardaria to synonymy of Lepidium (Al-Shehbaz et al. 2002) and Boleum to that of Vella (Warwick and Al-Shehbaz 1998) are fully justified.

Most of the smaller genera can easily be accommodated within larger ones if the morphological variation of their fruit characters are neither overemphasized nor used as the sole basis for generic delimitation. In fact, molecular studies provide ample support to that view. A classic example is the reduction of the South African Brachycarpaea (1 sp.), Cycloptychis E. Mey. (2 spp.), Schlechteria Bolus (1 sp.), Silicularia Compton (1 sp.), and Thlaspeocarpa C. A. Sm. (2 spp.) to synonymy of the larger Heliophila (previously 73 spp.), a genus within which all these smaller genera are nested (Al-Shehbaz and Mummenhoff 2005, Mummenhoff et al. 2005). Other examples are the reduction of Twisselmannia Al-Shehbaz and Agallis Phil. to synonymy of Tropidocarpum Hook. (Al-Shehbaz and Price 2001, AlShehbaz 2003a) and Euzomodendron Coss. and Boleum to synonymy of Vella (Warwick and Al-Shehbaz 1998).

Prior to the utilization of molecular data in phylogenetic studies, some of the larger genera (e.g. Arabidopsis, Arabis L., Sisymbrium L., Thlaspi L.) were considered to be natural, based on their fruit morphologies. However, it soon became evident that none of them are, and each had to be split into several segregates. For example, Arabis once included about 180 species worldwide (Al-Shehbaz 1988a), of 
which 80 occur in North America (Rollins 1993). The genus was delimited solely on the presence of linear latiseptate fruits (flattened parallel to the septum), accumbent cotyledons, and branched trichomes. As shown by AlShehbaz (2003b), this character combination evolved independently in at least 25 genera of the family. Molecular data (Koch et al. 1999a, 2000; O'Kane and Al-Shehbaz 2003; Beilstein et al. 2006) have clearly shown that the ten segregates of Arabis currently recognized (AlShehbaz 2003b, 2005) are unrelated to each other and to Arabis s.str., though they are remarkably similar in fruit morphology and cotyledonary position.

As for Arabidopsis, the approximately 60 species previously assigned to the genus are now placed in several segregate genera (AlShehbaz et al. 1999, Al-Shehbaz and O'Kane 2002a), and as presently delimited, the genus consists of only 11 species (O'Kane and AlShehbaz 1997, Warwick et al. 2005b). Similarly, Sisymbrium was once thought to consist of 90 species distributed both in the Old and New Worlds (Al-Shehbaz 1988b), but molecular studies (Warwick et al. 2002, 2005a) have shown that the genus consists of about 40 species, all except one of which ( $S$. linifolium Nutt.) are restricted to the Old World. The New World taxa previously assigned to Sisymbrium belong to an entirely different and morphologically distinct clade recognized by Warwick and Al-Shehbaz (2003) as the Thelypodieae alliance and herein at the tribal rank. Further molecular studies are needed to establish generic reassignments of the New World species of Sisymbrium. For these reasons, Sisymbrium still includes about 90 species in the checklist accompanying this issue (Warwick et al. 2006).

Earlier studies maintain Thlaspi as a large genus of over 80 species, and Meyer's (1973, 1979) 12 segregates, which were based largely on seed-coat anatomy, were not recognized (Hedge 1976, Al-Shehbaz 1986). The genus was delimited solely on its angustiseptate fruits (flattened at a right angle to the septum) with four or more seeds. However, molecular data
(Mummenhoff and Koch 1994; Zunk et al. 1996; Mummenhoff et al. 1997a, b; Koch and Mummenhoff 2001) strongly support the recognition of a few (Callothlaspi F.K. Mey., Microthlaspi F.K. Mey., Noccaea Moench, Noccidium F.K. Mey., and Vania F.K. Mey.) of Meyer's segregates. The data also show that the apparent similarities in fruit morphology are the result of convergence. As delimited by Meyer (2001)Thlaspi s.str. consists of only six species, and it is most closely related to Alliaria Heist. ex Fabr. than to the remaining species previously assigned to it.

To conclude, three important points need emphasis regarding the delimitation of genera. First, monotypic or oligotypic genera should not be established without prior molecular studies and critical evaluation of morphology. Second, because of widespread convergence in most morphological characters, especially fruit types and embryo position, these characters should be used with extreme care in establishing generic boundaries. Finally, major differences in fruit morphology can be misleading, and the examples of Heliophila, Tropidocarpum, and Vella should be a constant reminder about the dangers of making erroneous taxonomic conclusions by overemphasizing fruit morphology at the expense of other, potentially very useful vegetative and floral characters.

\section{Molecular data}

Numerous phylogenetic or genetic studies of the Brassicaceae have used chloroplast restriction fragment length polymorphisms (RFLPs), restriction site variation of cpDNA, or amplified fragment length polymorphisms (AFLP) fingerprinting. Although such studies provided a wealth of information and were consulted, they were not included in the present survey. However, the interested reader should consult Koch et al. (2003a) and Koch (2003) for a complete coverage on those and other markers.

Sequence comparisons of the internal transcribed spacers of the nuclear ribosomal DNA and the 5.8S rRNA gene (collectively, the ITS region) have been the most frequently used 
markers in assessing phylogenetic relationships in the Brassicaceae (see below). It should be admitted, however, that the utility of ITS sequences can be affected by the frequent occurrence of multiple copies of ITS, the effects of concerted evolution, and the need to clone this marker in such cases in order to obtain much more reliable data.

The second most frequently used markers are the non-coding regions from three tRNA genes in the large single-copy region of the chloroplast genome. These include the trn T (coding for threonine), $\operatorname{trn} \mathrm{L}$ (coding for leucine), and $\operatorname{trn} \mathrm{F}$ (coding for phenylalanine), as well as the $\operatorname{trn} \mathrm{L}$ intron, and $\operatorname{trn} \mathrm{T}-\operatorname{tr} n \mathrm{~L}, \operatorname{trn} \mathrm{L}-$ $\operatorname{trn} \mathrm{F}$, and $p s b \mathrm{~A}-t r n \mathrm{H}$ intergenic spacers.

Sequence data from the coding chloroplast gene $n d h \mathrm{~F}$ holds good promise for phylogenetic studies in the Brassicaceae (Beilstein et al. 2006) and it is hoped that more researchers utilize it in their studies, along with other single copy nuclear and chloroplast genes. About 930 species in 195 genera of Brassicaceae have been surveyed for one or more markers. Of these, ca. 250 species are native to Europe, ca. 210 to North America, ca. 180 to Asia, ca. 150 to Africa, ca. 80 to South America, and ca. 60 to Australia and New Zealand. Furthermore, over 730 species have been studied for ITS, 440 for trnL intron, 325 for the $t r n \mathrm{~L}-\mathrm{F}$ spacer, 130 for $n d h \mathrm{~F}$, about 100 for the $\operatorname{trn} \mathrm{T} / \mathrm{L}$ spacer, 60 for $m a t \mathrm{~K}, 50$ for $C h s$, and fewer species for other markers. The references used to compile these approximate figures are too voluminous to enlist in this publication, and they can be obtained directly from the first author.

Few molecular studies (Koch 2003, Beilstein et al.2006) have focused on the establishment of a family-wide phylogeny that would identify all major monophyletic clades. Most have focused on the tribal level or below (i.e. groups of closely related genera), with an emphasis on the delimitation of genera. These studies have been critical for determining representative taxa of monpophyletic groups that should be included in the larger family-based phylogenetic analyses. As indicated above, the sampling for each of the above markers covers less than $50 \%$ of the genera, and intensive efforts are needed to utilize single- or low-copy nuclear markers in addition to plastidic and mitochondrial ones. Furthermore, markers such as the pistillata gene (Bailey and Doyle 1999), arginine decarboxylase gene (Galloway et al. 1998), phytochromes (Beilstein, unpubl.), and mitochondrial NADH dehydrogenase intron (Franzke et al., unpubl.) hold promise, and they have not been utilized on a larger scale in phylogenetic studies. It is practically impossible to study all genera of the family. Perhaps what is most urgently needed is targeting key "diploid" species, especially with small genome size, that represent major clades or larger monophyletic genera in the family and conduct comprehensive, multilocus comparative studies that involve several chloroplast, nuclear, and mitochondrial genes.

We predict that the boundaries of some of the larger and medium-sized genera (e.g. Draba L. (363 spp.), Lepidium (231 spp.), Erysimum L. (223 spp.), Cardamine (197 spp.), Alyssum (195 spp.), Physaria (105 spp.), Rorippa Scop. (86 spp.), Heliophila (82 spp.), Isatis L. (79 spp.), Noccaea (77 spp.), Boechera A. Löve \& D. Löve (65 spp.), Aethionema (56 spp.), Biscutella L. (53 spp.), Matthiola R.Br. (48 spp.), Descurainia Webb \& Berthel. (48 spp.), Hesperis L. (64 spp.), and Crambe L. (34 spp.) are not going to be seriously altered in future studies (species numbers follow Warwick et al. 2006). Consequently, at least $70 \%$ of the species would be retained in their present genera. However, the groups that would be most affected are the monotypic and oligotypic genera, as well as Arabis and most members of the tribes Brassiceae and Schizopetaleae (see below). Other medium-sized genera, such as Malcolmia R.Br. (32 spp.), Parrya R.Br. (34 spp.), and Streptanthus (34 spp.), need critical studies to establish their monophyly.

\section{Major clades}

Despite the incomplete molecular knowledge of the Brassicaceae, a number of monophyletic clades or alliances have been identified based 
on Kropf (2002), Warwick et al. (2002, 2004a, 2004b, 2005a, 2005b), Koch (2003), Warwick and Sauder (2005), and Beilstein et al. (2006). Most of these major clades or alliances are recognized herein at the tribal level. Some were briefly covered in Koch et al. (2003a) and Mitchell-Olds et al. (2005), but extensive additional details of each are provided below.

On the basis of all markers surveyed thus far, the Brassicaceae are split into two, unequal, extremely well-resolved groups. The Aethionemeae clade is separated from the rest of the family by $100 \%$ bootstrap values (and a substantial branch length). The remainder of the family falls into an unresolved polytomy of several major clades within some of which are subclades supported by moderate to high bootstrap values (Fig. 1). This lack of resolution among the basal portion of the family appears to be the case with every marker surveyed thus far, including chloroplast and nuclear markers (see Kropf 2002, Koch 2003, Beilstein et al. 2006), as well as mitochondrial markers (Franzke and Mummenhoff, pers. com.). This lack of resolution suggests that major adaptive radiation(s) took place in the early evolutionary history of the family. It would be highly desirable to determine as accurately as possible the age of that initial radiation and to have a better understanding of the conditions that prompted it. It has been estimated that the Brassicaceae probably appeared some 50 million years ago (MYA) and that the split between Aethionema and the rest of the family was about 40 MYA (Koch et al. 2003a; Schranz, pers. com.).

The "basal" position of Aethionema does not necessarily mean that it has remained primitive. It is highly likely that the genus underwent adaptive radiation, similar to that observed in the rest of the family. Although some aspects of the genus, such as heterocarpy (see below), are not found elsewhere in the family, we hardly know anything about the evolution of that character. The next step will be to determine the morphology of the

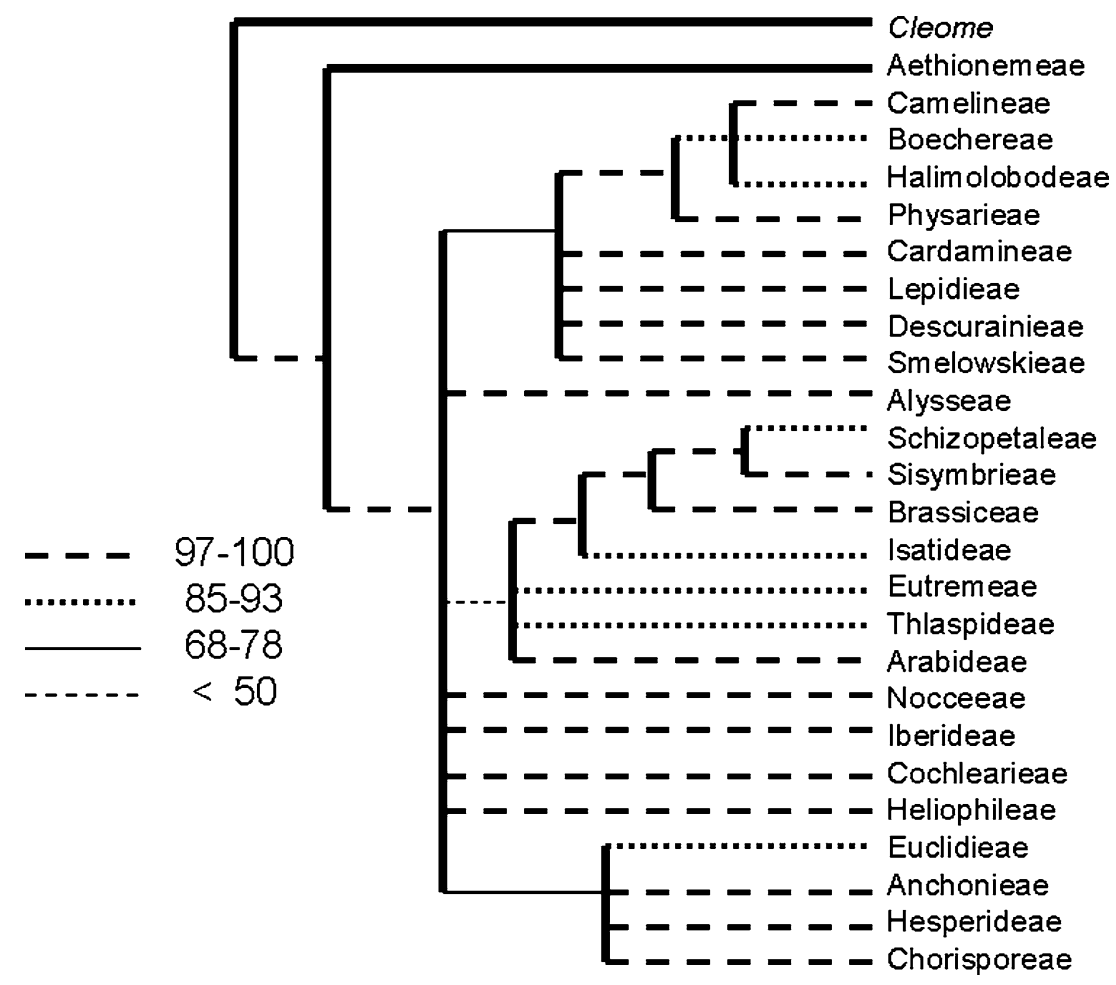

Fig. 1. Phylogenetic relationships among tribes of the Brassicaceae (modified from Beilstein et al. 2006) 
ancestral Brassicaceae prior to the Aethionema split from the rest of the family and what characters, if any, are symplesiomorphic (shared primitive ancestral characters) in the genus.

The overall topology of the family (minus Aethionema) shows major similarities in the analyses of multiple molecular markers by Koch (2003) and $n d h \mathrm{~F}$ by Beilstein et al. (2006). The family polytomy includes several monophyletic clades represented by the genera Arabidopsis, Draba, Brassica L., Thlaspi, Eutrema R.Br., Hesperis, and Noccaea. However, the topography and resolution among the clades represented by the above genera depended on the markers used. Taxonomic recognition at the tribal rank is given herein only to the major clades of the family, and the recognition of additional tribes, the placement of further genera, or the finer delimitation of the boundaries of each of these tribes would have to rely on future molecular studies. With a better sampling and further molecular studies on the family, the topology of some of the tribes might shift, but the overall infrastructure and principal component genera would most likely remain unchanged.

One might argue that it is premature to propose an incomplete tribal classification of the family because not all genera have been surveyed. The main reasons for giving taxonomic ranks to the principal clades are to provide a workable framework for the entire family, to enable direct and precise references to them in future studies, and to avoid the usage of potentially misleading words (e.g. alliance, lineage, group, clade, subdivision, infrafamilial taxon, assemblage, complex, sensu lato, sensu stricto, etc.). It is possible that future studies would necessitate revision(s) of the tribal architecture of the family, but the tribes proposed herein are much needed to encapsulate the progress made to date and to provide a general framework for future studies. Each tribe is defined morphologically and cytologically, and the approximate numbers of its component genera and species, as well as its overall distribution range, are given.
Numbers are based on the comprehensive species checklist (Warwick et al. 2006) and chromosome number index (Warwick and AlShehbaz 2006) provided in this issue. Genera of the 25 tribes listed below were compared to that of de Candolle (1821a, b), Prantl (1891), Hayek (1911) and Schulz's (1936) tribal classification to determine if any significant similarity patterns exist.

Tribe Aethionemeae. The tribe consists of two genera and 57 species distributed primarily in the Middle East and eastern Europe. Aethionema (56 spp.) is centered in Turkey but with fewer species extending eastward into Turkmenistan and westward into Spain and Morocco. Moriera occurs in Afghanistan, Iran and Turkmenistan.

Because of their "basal" and isolated position with respect to the rest of the Brassicaceae (Zunk et al. 1996, 1999; Koch 2003; Beilstein et al. 2006), the two genera are placed in one tribe. Schulz (1936) placed Aethionema, along with Thlaspi and Ionopsidium (DC.) Rchb., in the tribe Lepidieae subtribe Thlaspidinae Hayek, but molecular data show that Aethionema is not closely related to these two genera. He placed Moriera in the subtribe Iberidinae Hayek, but it is most likely that the genus is a spiny Aethionema.

Aethionema shows tremendous variation in habit (annual herbs to shrubs), floral structure (with or without appendages) and color, fruit morphology and heterocarpy (indehiscent 1seeded samaras or dehiscent, 1-8-seeded silicles on the same plant), and base chromosome numbers $(n=7,8,11,12,14,16,18,21,22,24$, 30). Some species of Aethionema are superficially very similar to the Middle Eastern Dipterygium Decne. (Cleomaceae), a monotypic genus that fluctuated between the Brassicaceae and Capparaceae (Hedge et al. 1980). Dipterygium glaucum Decne. (NE Africa and Arabia eastward into Pakistan) is a herb or shrub with entire linear leaves jointed at their attachment to the stem and with indehiscent, 1-seeded samaras (Kers 2003). Indeed, several species of Aethionema have the same combination of characters, but these appear to 
be the result of convergence, as Dipterygium is not basal in the Cleomaceae (Hall et al. 2002). Kers (2003) suggested that Dipterygium may be treated as a monotypic family.

Appel and Al-Shehbaz (2003) reduced Eunomia DC. (1 sp.) to synonymy of Aethionema, but Hall et al. (2002) and Menke (pers. com.) showed that Eunomia oppositifolia (Pers.) DC. is unrelated to Aethionema or Iberis and should therefore be re-instated as independent genus. However, the systematic position of Eunomia needs to be resolved, as does the taxonomic placement of the ca. 16 species previously assigned to it.

Despite the important role that Aethionema holds in understanding the early evolution of the family, we know rather little about the genome size, chromosome numbers, and morphology of its basal species, its phylogeny, and what makes it most basal in the family. Phylogenetic studies addressing all of these matters are in progress (Menke, pers. com.).

Tribe Camelineae. The tribe includes 12 13 genera and some 240 species distributed primarily in Eurasia, with minor representations in North America and Australia-New Zealand (ca. 20 spp. each). It includes Arabidopsis (11 spp.), Camelina Crantz (11 spp.), Capsella Medik. (5 spp.), Catolobos (C.A. Mey.) Al-Shehbaz (1 sp.), Crucihimalaya AlShehbaz, O'Kane \& R.A. Price (9 spp.), Erysimum (223 spp.), Neslia Desv. (1 sp.), Olimarabidopsis Al-Shehbaz, O'Kane \& R.A. Price (3 spp.), Pachycladon Hook.f. (including Cheesmania O.E. Schulz and Ischnocarpus O.E. Schulz) (10 spp.), Pseudoarabidopsis AlShehbaz, O'Kane \& R.A. Price (1 sp.), Transberingia Al-Shehbaz \& O'Kane (1 sp.), Turritis L. (2 spp.), and perhaps Stenopetalum R.Br. ex DC. (10 spp.).

De Candolle (1821a) placed Camelina, Neslia, and Stenopetalum in the Camelineae, but these were placed in different tribes and subtribes by Hayek (1911) and Schulz (1936). Schulz (1924, 1936) placed Arabidopsis, together with a heterogeneous assemblage of genera, in the Sisymbrieae subtribe Arabidopsidinae. These include the New
World Sphaerocardamum Shauer, Halimolobos Tausch, Pennellia Nieuwl., and several Australian and Asian members. As shown below, the last three genera belong to the Halimolobeae, a tribe related to the Camelineae, but the placement of the Australian and some Asian genera remain uncertain.

The Camelineae includes primarily annuals (most Erysimum are perennials) with stalked or sessile stellate trichomes often mixed with simple ones (Erysimum has exclusively sessile stellate or malpighiaceous trichomes). The base chromosome number is predominantly $x=8$, though it is reduced to $n=5$ in Arabidopsis thaliana and $n=4$ in Stenopetalum (Shaw 1972), and shows a continuous series $x=6-11$ in Erysimum. Except for Capsella, all members of the tribe have either terete, latiseptate, or quadrangular fruits. Capsella has angustiseptate fruits and, together with Neslia and Camelina, they have silicles instead of siliques. However, the nearest relative of Capsella appears to be Catolobus, a genus with linear, latiseptate fruits (Al-Shehbaz 2005).

Because of extensive use of Arabidopsis thaliana in experimental biology, the genus and related genera have been well studied (e.g. Mummenhoff and Hurka 1994, 1995; Price et al. 1994, 2001; O'Kane and Al-Shehbaz 1997, 2003; O'Kane et al. 1997; Al-Shehbaz et al. 1999; Koch et al. 1999a, 2000, 2001; Mitchell and Heenan 2000; Al-Shehbaz and O'Kane 2002a; Heenan and Mitchell 2003; Heenan et al. 2002; Beilstein et al. 2006). These molecular studies strongly support the close relationship among these genera.

Although this tribe and the next eight are related and, together, form a clade with $78 \%$ bootstrap support in the $n d h \mathrm{~F}$ phylogeny of Beilstein et al. (2006), the group received less than 50\% support in Koch's (2003) combined ITS, Chs, matK, and Adh analyses.

Tribe Boechereae. This new tribe is almost exclusively North American, and thus far only one species, Boechera furcata (Turcz.) Al-Shehbaz, grows in the Russian Far East (Al-Shehbaz 2005). The Boechereae includes seven genera and about 110 species most of 
which belong to Boechera, and the rest represent the monotypic Anelsonia J.F. Macbr. \& Payson, Nevada N.H. Holmgren, Phoenicaulis Nutt., and Sandbergia Greene, and the ditypic Cusickiella Rollins and Polyctenium Greene.

Schulz (1936) recognized Sandbergia as a member of the tribe Sisymbrieae, reduced Polyctenium to Smelowskia of that tribe, and placed Cusickiella (as Cusickia A. Gray), Anelsonia, Phoenicaulis, and Boechera (as Arabis) in the tribe Arabideae. All members of the tribe typically have a base chromosome number of $x=7$, mostly entire leaves (except Polyctenium and Sandbergia), and branched trichomes (absent or in few Boechera and simple in Nevada). The majority are perennials with a well-defined basal rosette.

Rollins (1993) treated all species of Boechera as members of Arabis, but extensive molecular studies (summarized in Al-Shehbaz $2003 \mathrm{~b}$ ) indicate that the two genera are unrelated. Monophyly of the tribe is supported by the works of Beilstein et al. (2006) and Bailey et al. (pers. com.). Boechera is taxonomically quite difficult, and much of its complexity is the product of hybridization, polyploidy, and apomixis (see below).

Tribe Halimolobeae. This new tribe, first recognized by Bailey et al. (2002) as the halimolobine alliance, includes five genera and about 40 species. It is an exclusively New World group, the ranges of most species of which are in central and northern Mexico, though three reach the southwestern United States and several are disjunct in South America (Bailey 2001, Fuentes-Soriano 2004). The tribe includes Halimolobos (7 spp.), Mancoa Wedd. (11 spp.), Pennellia (9 spp.), Sphaerocardamum (8 spp.), and a new genus of eight species to be segregated from Halimolobos (Bailey and Al-Shehbaz, in prep.). Both Mancoa and Pennellia have disjunct centers of distribution, a Mexican-southwestern US center and a South American center.

Schulz (1924, 1936) placed Halimolobos, Pennellia, and Sphaerocardamum in the Sisymbrieae subtribe Arabidopsidinae, whereas both Mancoa and Cibotarium O.E. Schulz were assigned to the Lepidieae because of their angustiseptate silicles. Cibotarium and Sphaerocardamum were shown to be congeneric (Rollins 1984, Bailey 2001). In the combined molecular and morphological analysis of Bailey et al. (2002), as well as the $n d h \mathrm{~F}$ studies by Beilstein et al. (2006), the tribe formed a monophyletic group.

The Halimolobeae have branched trichomes, white (rarely purplish flowers), seeds mucilaginous when wetted, ebracteate racemes (except in two Mancoa), often spreading sepals, and a base number of $x=8$.

Tribe Physarieae. The tribe, first identified as a monophyletic clade by O'Kane and AlShehbaz (2003), consists of seven genera and ca. 150 species. It is distributed primarily in North America, and only five species of Physaria are disjunct in South America (N Argentina and S Bolivia) and one, P. arctica (Wormsk. ex Hornem) O'Kane \& Al-Shehbaz, is circumpolar (Al-Shehbaz and O'Kane 2002b, O'Kane and Al-Shehbaz 2004). In addition to the approximately 105 species of Physaria (including Lesquerella S. Wats.), the tribe includes Dimorphocarpa Rollins (4 spp.), Dithyrea Harv. (2 spp.), Lyrocarpa Hook. \& Harv. (3 spp.), Nerisyrenia Greene (8 spp.), Paysonia O'Kane \& Al-Shehbaz (8 spp.), and Synthlipsis A. Gray (2 spp.). The genera Dithyrea, Lesquerella, Lyrocarpa, Physaria, and Synthlipsis were originally assigned to the Physarieae by Robinson (1895) and are retained here.

Although the tribe Physarieae is welldefined, its members were placed by Schulz (1936) in various tribes. For example, Physaria was placed in the Lepidieae subtribe Physariinae, whereas Lesquerella (now a synonym of Physaria; see Al-Shehbaz and O'Kane 2002b) was placed in the Drabeae. He placed the remaining genera in the Lepidieae subtribes Lyrocarpinae (Lyrocarpa), Iberidinae (Dithyrea), and Capsellinae (Nerisyrenia (as Greggia A. Gray) and Synthlipsis).

The Physarieae are readily distinguished from the rest of the Brassicaceae by having pollen with four or more colpi (the rest of 
Brassicaceae are tricolpate), typically sessile stellate trichomes (though simple, forked, and stalked substellate trichomes occur in Paysonia species), two or more ovules per locule, and angustiseptate or inflated silicles (some Nerisyrenia have siliques). A reversal to the tricolpate state apparently occurred in one species of Lyrocarpa. Most species have a base chromosome number of $x=8$, though a continuous series of aneuploid reduction to $n=4$ and increase to $n=11$, plus various ploidy levels, have been reported. Genome size, chromosomal evolution, and phylogeny of this tribe are currently being studied by Sara FuentesSoriano.

Tribe Cardamineae. This tribe of ten genera and over 340 species includes the core genera Cardamine (including Dentaria L. and Iti Garn.-Jones) (197 spp.) and Rorippa (86 spp.), both of which grow on all continents except Antarctica, the Eurasian Armoracia P. Gaertn., B. Mey. \& Scherb. (3 spp.), Barbarea R.Br. (29 spp.), Nasturtium R.Br. (5 spp.; 2 are native to Mexico and the United States), and the North American Iodanthus Torr. \& A. Gray ex Steud. (1 sp.), Leavenworthia Torr. (8 spp.), Ornithocarpa (2 spp.), Planodes Greene (1 sp.), and Selenia Nutt. (4 spp.). Based on morphology, it appears that the Australian Arabidella (F. Muell.) O.E. Schulz (6 spp.) is closer to members of the Cardamineae than to those of other tribes, but this assumption needs to be tested with molecular data.

Schulz (1936) placed Armoracia in the tribe Drabeae, Selenia in the Lunarieae, Ornithocar$p a$ in the Schizopetaleae, Iodanthus in the Matthioleae, and the remaining five genera in the Arabideae. He reduced Rorippa to synonymy of Nasturtium, but as shown by AlShehbaz and Price (1998), Franzke et al. (1998), and Bleeker et al. (1999, 2002b), the two are sufficiently distinct, and Nasturtium is closest to Cardamine, whereas Rorippa is nearest to Barbarea. The tribe has been subjected to several molecular studies [including Les (1994), Franzke et al. (1999), Bleeker et al. (2002a, b), Sweeney and Price (2000), and references therein] that support its monophyly.

Members of the Cardamineae grow predominantly in mesic or aquatic habitats and are characterized by having pinnately divided or compound (rarely palmately compound or simple) leaves, simple or no trichomes, accumbent cotyledons, latiseptate or terete (angustiseptate in Armoracia) fruits, and a base number of $x=8$. Subularia L. (2 spp.), which also occupy aquatic or mesic habitats, might belong to this tribe. Aneuploid series above and below $x=8$, as well complex polyploidy, have been well documented in the tribe, especially in Cardamine (see Marhold and Lihova in this issue) and Rorippa.

Tribe Lepidieae. The Lepidieae consists of three to five genera and over 240 species. It is represented by core genus Lepidium (including Cardaria Desv., Coronopus Zinn., and Stroganowia Kar. \& Kir.) (231 spp.), which is distributed on all continents except Antarctica, the monotypic Acanthocardamum Thell. (Afghanistan) and Delpinophytum Speg. (Argentina), and perhaps the Middle Eastern and Central Asian Stubendorffia Schrenk ex Fisch. \& Avé-Lall. (8 spp.) and Winklera Regel (3 spp.).

Although Schulz (1936) placed all of the above genera in the Lepidieae, his delimitation of this tribe, which he divided into 13 subtribes, was based solely on the presence of angustisptate fruits. The artificiality of such circumscription led to his assignment of many unrelated genera to this tribe. For example, Aethionema, Thlaspi, Isatis and relatives, Tropidocarpum, Physaria, Iberis, Cochlearia L., Lyrocarpa, Synthlipsis, Capsella, Hedinia Ostenf., and Hornungia Rchb. are assigned in this account to at least nine tribes. Obviously, angustiseptate fruits evolved independently many times within the family.

The tribe is characterized by the presence of angustiseptate fruits (secondarily inflated in two species previously placed in Cardaria), one ovule per locule, often mucilaginous seeds, simple or no trichomes, and a base number of $x=8$. The extensive molecular studies on 
Lepidium and related genera (Mummenhoff 1995; Bowmann et al. 1999; Mummenhoff et al. 2001a, 2004) were relied on to draw the boundaries of this tribe.

A group of several Australian species of Lepidium that are shrubs with either incumbent or diplecolobal cotyledons (Hewson 1981) seem to form a distinct group separate from the rest of the genus (Mummenhoff, pers. com.). It would be interesting to subject this group to further studies to elucidate its generic and tribal status. Evidently, diplecolobal cotyledons evolved in this group independently from that of the South African genus Heliophila.

Tribe Alysseae. The Alysseae are maintained herein as a tribe because the vast majority of Alyssum and at least some of the genera would form a monophyletic group that deserve a tribal rank. The tribe is Eurasian and North African, and only one species, Alyssum obovatum (C.A. Mey.) Turcz., extends it native range from northern and central Asia into northern North America. As delimited by Schulz (1936) and expanded by Dudley and Cullen (1965), the tribe would probably consist of over 280 species the bulk of which (ca. 195) falls in Alyssum. Only a few species each of Alyssum, Aurinia Desv. (9 spp.), Berteroa DC. (5 spp.), Farsetia Turra (27 spp.), and Lobularia Desv. (4 spp.) have been included in molecular studies. The tribe most likely also includes Alyssoides Mill. (2 spp.), Asperuginoides Rauschert (1 $\mathrm{spp}$.), Bornmuellera Hausskn. (7 spp.), Clastopus Bunge ex Boiss. (2 spp.), Clypeola L. (9 spp.), Degenia Hayek (1 sp.), Didymophysa Boiss. (2 spp.), Fibigia Medik. (13 spp.), Galitzkya V.V. Botschantz. (3 spp.), Hormathophylla Cullen \& T.R. Dudley (10 spp.), Physoptychis Boiss. (2 spp.), and Straussiella Hausskn. (1 sp.). Detailed phylogenetic and systematic studies are much needed in order to determine tribal assignment of genera, as well as the position of the Alysseae in relation to the other tribes.

It is unlikely that Alyssum is monophyletic and that some of its segregates (e.g. Ptilotrichum C. A. Mey.) are perhaps unrelated and worthy of separate recognition. The latter genus likely belongs to the tribe Arabideae, to which it shows more morphological affinities than to Alyssum.

The Alysseae is characterized by having stellate trichomes, latiseptate or terete (rarely angustiseptate), mostly few-seeded silicles, usually appendaged filaments, often winged seeds, and a base number of primarily $x=8$, though lower and higher aneuploid series exist but are rare. Trichome morphology in the tribe shows remarkable similarity to that of the Physarieae, but evidently that similarity evolved through convergence, and members of the two tribes are readily distinguished by the number of pollen colpi discussed above.

Tribe Descurainieae. This new tribe consists of about six genera and some 60 species distributed in the Americas, Eurasia, and Africa. It includes up to 48 species of Descurainia (including Hugueninia Rchb.), and the smaller Eurasian Hornungia (3 spp.), central Asian Ianhedgea Al-Shehbaz \& O'Kane (1 sp.), North-South American Tropidocarpum (4 spp.), and the monotypic Middle Eastern Robeschia Hoschst. ex O.E. Schulz and the Patagonian Trichotolinum O.E. Schulz. The last two might not be sufficiently distinct from Descurainia. The tribe appears to be monophyletic based on preliminary studies by Beilstein et al. (2006), Price (pers. com.), and Goodson (pers. com.). Descurainia is centered in the Canary Islands (7 spp.) and North and South America.

Schulz (1924, 1936) treated the Descurainieae as a subtribe of the Sisymbrieae, but the available data clearly indicate that the two taxa are remotely related. Furthermore, he included Smelowskia and its allies in that subtribe, but the two groups, though closely related, appear to merit independent status (see below).

The tribe consists of herbs (Descurainia is secondarily woody on the Canary Islands), with petiolate, 1-3-pinnatisect cauline leaves, dendritic or rarely only forked trichomes, often numerous tiny seeds, incumbent cotyledons, predominantly yellow flowers, and a 
base number of $x=7$, though an aneuploid reduction to $x=6$ is found in Hornungia. Many species of Descurainia have unicellular, glandular papillae, a structure not found elsewhere in the family.

Tribe Smelowskieae. This new unigeneric tribe consists of Smelowskia (25 spp., see recent revision by Al-Shehbaz and Warwick 2006a). Molecular studies supported the inclusion of Hedinia (4 spp.), Sophiopsis O.E. Schulz (4 spp.), Sinosophiopsis Al-Shehbaz (3 spp.), and the monotypic Redowskia Cham. \& Schltdl. and Gorodkovia Botsch. \& Karav. within Smelowskia (Warwick et al. 2004b). The expanded Smelowskia is centered in eastern and central Asia, and only seven species are native to northern North America. The tribe also includes Ermania Cham. ex Botsch. (1 sp.), a genus that Schulz (1936) had placed in the Arabideae.

Based on the presence of pinnatisect leaves and branched trichomes, Schulz (1924, 1936) placed Smelowskia, Sophiopsis, and Redowskia in the Sisymbrieae subtribe Descurainiinae. Although Hedinia also has the same leaf and trichome characters, he (1936) assigned it to the tribe Lepidieae because of having angustiseptate fruits. However, Warwick et al. (2004b) demonstrated that there are no solid morphological grounds to maintain the smaller genera above as independent of Smelowskia.

In addition to the pinnatisect and petiolate cauline leaves and branched trichomes, the tribe consists of perennials (sometimes secondarily annual) with white (rarely cream) flowers, several- to many-seeded fruits, nonmucilaginous seeds, incumbent cotyledons, and base chromosome number of $x=6$, though higher polyploids with $n=12$ and aneuoploid reductions to 11 and 10 have been well documented.

Tribe Arabideae. The Arabideae comprise at least six genera and over 460 spp. distributed primarily in Eurasia and North America north of the Tropic of Cancer (except 70 species of Draba distributed along the high Andes of South American from Colombia southward into Patagonia). The tribe consists of Draba (including Drabopsis K. Koch, Erophila DC. and Schivereckia Andrz. ex DC.), Arabis (excluding Boechera, Turritis, and Fourraea Greuter \& Burdet and others; see below), Aubrieta (12 spp.), Baimashania AlShehbaz (2 spp.), and perhaps Athysanus Greene (2 spp.). Despite being the largest in the family and one of the most diversified morphologically, Draba (363 spp.) is a monophyletic genus (Koch and Al-Shehbaz 2002). The exact number of species in Arabis is unknown, but it is definitely much less than the 118 spp. listed by Warwick et al. (2006), whose higher estimate resulted from the lack of thorough phylogenetic study on the genus. Koch (2003) showed the "tribe" to be sister to Arabis turrita L., now Pseudoturritis Al-Shehbaz (1 sp.), and Berteroella (1 sp.), but these two genera should probably be assigned to the Arabideae. On overall morphological grounds, Ptilotrichum, often treated as a synonym of Alyssum (Zhou et al. 2002), may well belong to this tribe.

It is likely that the eastern and central Asian Stevenia Adams \& Fisch. (4 spp.) Pachyneurum Bunge (1 sp.), and Macropodium R.Br. (2 spp.) belongs to the Arabideae. The last genus was assigned by several authors (e.g. Hayek 1911, Schulz 1936, Al-Shehbaz 1973, Hauser and Crovello 1982) to the tribe Schizopetaleae (as Thelypodieae) because it has stipitate fruits and exserted stamens, but it is very likely that these characters evolved independently in the two taxa.

As delimited by Schulz (1936), the Arabideae consisted of genera (or their synonyms) herein assigned to the Cardamineae (Cardamine, Leavenworthia, Barbarea, Planodes, Nasturtium, Kardamoglyphos Schltdl.), Schizopetaleae (Pleurophragma Rydb., Guillenia Greene, Sibara Greene), Boechereae (Phoenicaulis, Anelsonia, Borodinia N.Busch), Camelineae (Cheesmania, Cardaminopsis Hayek), Eutremeae (Neomartinella Pilg.), Ermania Cham. ex Botsch. (Smelowskieae), and Dontostemon Andrz. ex C.A. Mey. (Anchonieae). He distinguished the Arabideae solely by the presence of latiseptate 
siliques and accumbent cotyledons, two character states that evolved independently or together many times in the Brassicaceae. By contrast, the bulk of his tribe Drabeae consisted of Draba (as delimited herein), Cusickia (now Cusickiella of the Boechereae), Lesquerella (now Physaria of the Physarieae), and Trochiscus O.E. Schulz (now Rorippa) and Armoracia of the Cardamineae.

The Arabideae are characterized by having branched trichomes, accumbent cotyledons (incumbent in Berteroella O.E. Schulz), often latiseptate fruits (terete in Berteroella and some Draba and Aubrieta Adans.), nonmucilaginous seeds, entire or dentate leaves, and a base number of $x=8$, though higher and lower aneuploidy series and extensive polyploidy are common in Draba.

Arabis is undoubtedly the most problematic genus in the group, and it is an ideal example where convergence in fruit morphology has led to unreliable and chaotic taxonomy (see Al-Shehbaz 2003b). Prior to molecular studies, Arabis consisted of about 180 species (Al-Shehbaz 1988a, Rollins 1993), but beginning with the works of Koch et al. (1999a, 2000) and subsequently O'Kane and Al-Shehbaz (2003), this genus has been considerably reduced in size. Boechera, Fourraea, Catolobus, and Pseudoturritis are among its recent generic segregates that are neither closely related to Arabis nor to each other (Al-Shehbaz 2003b, 2005). Turritis was established in 1753 by Linnaeus, but most recent authors (e.g. Rollins 1993, Akeroyd 1993, Mulligan 1996, Tan 2002) unite it with Arabis. As shown by Koch (2003) and Beilstein et al. (2006) and discussed above, Turritis belongs to the Camelineae, and clearly is remotely related to Arabis s.str.

Despite the redefinition of its limits, Arabis remains paraphyletic and heterogeneous because its type species ( $A$. alpina L.) is sister to Draba and Aubrieta rather than to most of the Eurasian and North American species still retained in it (Koch 2003). Therefore, the genus remains problematic, and more studies are needed to establish its monophyly and delimit its boundaries. Species delimitation is also problematic, for example, A. hirsuta (L.) Scop. is said to be native to Europe, Asia, and North America (Rollins 1993, Zhou et al. 2002) based solely on superficial morphological grounds, and would appear to involve more than one species.

Tribe Brassiceae. Because of the economically important Brassica and its relatives, this tribe has received considerable molecular studies (summarized in Warwick and Black 1997a, 1997b; Warwick and Sauder 2005), all of which support it as the only monophyletic tribe among the 19 recognized by Schulz (1936). The tribe consists of 46 "genera" and about $230 \mathrm{spp}$. characterized primarily by having conduplicate cotyledons, and/or segmented (heteroarthrocarpic) fruits and simple or no trichomes (for genera and number of species, see Gómez-Campo 1999, Appel and Al-Shehbaz 2003, Warwick and Sauder 2005 and references therein). The few exceptions to this character combination are Ammosperma Hook.f. (2 spp.) and Pseuderucaria (Boiss.) O.E. Schulz (2 spp.), neither of which has the conduplicate cotyledons or the segmented fruits. The delimitation of the tribe has not changed drastically since the detailed work of Schulz $(1919,1923)$. Except for the four species of Cakile Mill. native to North America, the Brassiceae is primarily Mediterranean and southwest Asian, though its range extends southward into South Africa.

Calepina Adans. (1 sp.) and Conringia Heist. ex Fabr. (6 spp.) were once included in the Brassiceae (Schulz 1936, Al-Shehbaz 1985b, Gomez-Campo 1999), but recent studies (Anderson and Warwick 1999, FranciscoOrtega 1999, Lysak et al. 2005, Warwick and Sauder 2005, Beilstein et al. 2006) clearly support their exclusion from this tribe. In our opinion, both genera should be removed from the Brassiceae, and the alleged conduplicate cotyledons present in Calepina and a species of Conringia do not appear to be homologous to those of typical members of the tribe.

No other group in the entire family shows as much fruit diversity as that of the 
Brassiceae. The vast majority of genera are readily recognizable by their fruits, but in every other aspect of vegetative and floral morphology, and molecular marker surveyed thus far, they are inadequately distinguishable. This lack of molecular, vegetative, and floral differentiations, as opposed to the tremendous fruit differentiation, was discussed above. It is concluded that rapid evolutionary bursts of fruit morphology, which are probably controlled by a relatively few genes, have most likely occurred independently of other aspects of morphology, and therefore obstructed the true relationships within the tribe and led to inadequate taxonomy.

The extensive molecular studies by Warwick and her colleagues (see Warwick and Sauder 2005) on this tribe clearly demonstrate that generic boundaries, as traditionally recognized (Schulz 1936, Gómez-Campo 1999), need to be revised. Except for a few genera such as Cakile (perhaps including Erucaria Gaertn. and Didesmus Desv.), Vella (including Euzumodendron and Boleum), and Crambe (see Warwick and Black 1994, 1997b; Francisco-Ortega 1999, 2002 and references therein), the rest of the Brassiceae falls into two groups somewhat weakly defined molecularly but not morphologically: the nigra and rapa clades. Generic limits, if indeed possible to establish within the rapa and nigra clades, should reflect the extensive molecular data available. In fact, some of the most commonly known genera of the Brassiceae (e.g. Brassica, Diplotaxis DC., Erucastrum C. Presl, Sinapis L., Raphanus L., Rapistrum Crantz, Eruca Mill., Sinapidendron Lowe, Hemicrambe Webb, Hirschfeldia Moench) need to be abandoned despite the fact they are "traditional" and include economically important or weedy taxa. Naturally, traditionalists would resist such major alterations, but the vast majority of botanists believe that taxonomy must reflect phylogenetic data, and nomenclatural changes will have to be made sooner or later.

The Brassiceae, together with the Schizopetaleae, Sisymbrieae, and Isatideae, form a reasonably well-defined clade with over $90 \%$ bootstrap support in Beilstein et al. (2006) but are less resolved in Koch (2003).

Tribe Schizopetaleae. This is earliest published name for the tribe (Barnéoud 1845), and the name should replace the most commonly used Thelypodieae. The Schizopetaleae consist of about 230 species in at least 20 genera, all except the monotypic Pringlea Anderson ex Hook.f. (South Indian Ocean islands) are restricted to the New World. In addition to this genus, the tribe includes Caulanthus S. Wats. (17 spp.), Chaunanthus O.E. Schulz (3 spp.), Chilocardamum O.E. Schulz (2 spp.), Chlorocrambe Rydb. (1 sp.), Dryopetalon A. Gray (5 spp.), Hesperidanthus (B.L. Rob.) Rydb. (5 spp.), Neuontobotrys O.E. Schulz (5 spp.), Romanschulzia O.E. Schulz (13 spp.), Schizopetalon (10 spp.), Sibara Greene, (9 spp.), Sibaropsis S. Boyd \& T.S. Ross (1 sp.), Stanleya Nutt. (6 spp.), Streptanthella Rydb. (1 sp.), Streptanthus Nutt. (34 spp.), Thelypodium Endl. (19 spp.), Thleypodiopsis Rydb. (17 spp.), Thysanocarpus Hook. (5 spp.), Warea Nutt. (4 spp.), Weberbauera Gilg \& Muschl. (23 spp.), and Werdermannia O.E. Schulz (5 spp.).

The limits of the Schizopetaleae are still unclear, and the South American Brayopsis Gilg. \& Muschl. (6 spp.), Catadysia O.E. Schulz (1 sp.), Dactylocardamum Al-Shehbaz (1 sp.), Dictyophragmus O.E. Schulz (2 spp.), Englerocharis Muschl. (2 spp.), Eremodraba O.E. Schulz (2 spp.), Eudema Humb. \& Bonpl. (6 spp.), Lithodraba Boelcke (1 sp.), Mathewsia Hook. \& Arn. (10 spp.), Onuris Phil. (6 spp.), Petroravenia Al-Shehbaz (1 sp.), Sarcodraba Gilg \& Muschl. (3 spp.), and Xerodraba Skottsb. (7 spp.) should be studied in connection with this tribe. If added, they will bring the total in the Schizopetaleae to over 330 species and about 35 genera. Warwick et al. (2002) demonstrated that all except one of the New World species previously assigned to Sisymbrium ( $S$. linifolium) belong to the Schizopetaleae (as Thelypodieae), and some 40 South American species await generic assignments. 
As delimited by Al-Shehbaz (1973), the tribe includes four of Schulz's (1936) tribes (Stanleyeae, Pringleeae, Streptantheae, Romanschulzieae). Many genera presently assigned to the Schizopetaleae were placed by Schulz (1936) in other tribes. These include Dryopetalon and Schizopetalon (Schizopetaleae), Thysanocarpus (Lunarieae), Guillenia and Sibara (Arabideae), Hesperidanthus (Matthioleae), Thelypodium and Thleypodiopsis (Hesperideae), and about 20 South American genera and over 40 species of Sisymbrium (Sisymbrieae).

Although not all species of the tribe are surveyed cytologically, the base chromosome number is primarily $x=14$ and its descending aneuploid series to $x=10$. The majority of taxa are either glabrous or with simple trichomes, but many South American members evolved branched ones. The fruits are primarily siliques, but silicles must have evolved independently in the North American Thysanocarpus and several South American genera.

Unlike the Brassiceae, the Schizopetaleae exhibit tremendous floral (instead of fruit) diversity, not paralleled anywhere in the family. Floral diversity includes differences in filament length (equal, tetradynamous, or three unequal lengths), exsertion vs. inclusion of stamens, coiling of linear anthers vs. uncoiling of ovate or globose anthers, presence vs. absence of gynophore, elaboration of corolla vs. its reduction, presence vs. absence of style, actinomorphy vs. zygomorphy, wind vs. insect pollination, and every conceivable flower color in the family, especially in Streptanthus. This genus is quite heterogeneous in floral morphology, and it is likely that some of Greene's seven segregates (see Appel and AlShehbaz 2003) would merit recognition.

Indeed, the streptanthoid genera (with crisped or channeled petals, often urceolate calyx, stamens in three lengths, and somewhat zygomorphic flowers), which include Sibaropsis, Streptanthella, most of Caulanthus, and Streptanthus are unique in the family by having this flower combination. However, they were maintained by Rollins (1993) and Appel and Al-Shehbaz (2003) because of small differences in fruit compression and cotyledonary position. In our opinion, species with typically streptanthoid flowers ought to be studied carefully to determine whether they represent one genus or their character combination evolved independently.

The almost complete lack of ITS (Warwick et al. 2002, 2005a) and $n d h \mathrm{~F}$ (Beilstein et al. 2006) resolution among members of the Schizopetaleae suggests a relatively recent evolution of the group and insufficient time for the molecular markers studied to diverge. This poor resolution is in agreement with the difficulty in recognizing genera in the tribe. It is premature to make rigid conclusions when not all genera have been examined and where molecular data to date provides little support for generic delimitation. It would also be a mistake to unite members of the Schizopetaleae into one or few genera, given the remarkable floral differentiation in the group. These acute problems need to be addressed critically by additional molecular and morphological studies.

Tribe Sisymbrieae. As it stands now, this tribe consists of only about 40 species of Sisymbrium (including Lycocarpus O.E. Schulz and Schoenocrambe Greene), all except one North American species of which (S. linifolium) are distributed in Eurasia and Africa. Further studies are needed to determine if other genera, such as Murbeckiella Rothm. (5 spp.) and Nasturtiopsis Boiss. (1 sp.), belong to this tribe.

The Sisymbrieae was recognized as a tribe of 70 genera and 400 species (Schulz 1936, Al-Shehbaz 1988c), but molecular data (see Warwick et al. 2002, 2004a, 2004b, 2005; Koch 2003; Koch et al. 2003a) supported the removal of many of its component genera to other tribes. The tribe is monophyletic and is sister to the Schizopetaleae (Beilstein et al. 2006) or the Brassiceae (Warwick et al. 2002, Koch 2003). The Sisymbrieae are characterized by having terete siliques, simple or no trichomes (only the South African Sisymbrium bruchellii DC. has branched trichomes), 2-lobed stigmas, a base 
chromosome number of $x=7$, often pinnately divided lower leaves, and yellow flowers.

Tribe Isatideae. This tribe of over 90 species in eight genera was first recognized by Hayek (1911) as a subtribe of the Arabideae and by Schulz (1936) as a subtribe of the Lepidieae. Koch et al. (2003a) suspected that it forms a monophyletic group based strictly on morphology. Molecular data (Beilstein et al. 2006) show that Isatis (79 spp.) and Myagrum L. (1 sp.) form a monophyletic group (93\% bootstrap support) sister to a clade including the tribes Brassiceae, Schizopetaleae, and Sisymbrieae. Although not included in any molecular studies thus far and based strictly on the overall morphology, it is highly likely that the tribe also includes the genera Pachypterygium Bunge (3 spp.), Sameraria Desv. (9 spp.), and the monotypic Boreava Jaub. \& Spach, Chartoloma Bunge, Glastaria Boiss., Schimpera Hochst. \& Steud. ex Endl., Spirorrhynchus Kar. \& Kir., Tauscheria Fisch. ex DC. Both Myagrum and Tauscheria were placed by de Candolle (1821a) with Isatis (including Sameraria) in the Isatideae. The limits of Isatis are controversial, and with critical studies, it is likely that the total number of species be reduced to a little over 50 .

The Isatideae have yellow or rarely white flowers, simple or no trichomes, auriculate cauline leaves, indehiscent, 1- or 2-seeded, often pendulous fruits, and a base chromosome number of $x=7$. The differences between the constituent genera of the tribe are minor and rest exclusively on fruit morphology. It is likely that at least some of the genera above would be eventually united with Isatis.

Tribe Eutremeae. This primarily Asian tribe comprises about 25 species, of which the ranges of one species each of Eutrema (10 spp.) and Thellungiella O.E. Schulz (3 spp.) extend into northern North America. Warwick et al. (2005b) showed that Neomartinella (3 spp.), Platycraspedum O.E. Schulz (2 spp.), Taphrospermum C.A. Mey. (7 spp.), and Thellungiella are nested within Eutrema and are therefore united into one genus (Al-Shehbaz and Warwick 2006b). O'Kane and
Al-Shehbaz (2003) showed the same results regarding the last two genera. In Beilstein et al. (2006), Chalcanthus Boiss. (1 sp.) and Taphrospermum are sister taxa with $100 \%$ support. Clearly, more work is needed in the tribe.

Based on differences in fruit compression and cotyledonary position, Schulz (1936) placed Eutrema and Taphrospermum in the Sisymbrieae subtribe Alliariinae, Thellungiella in the Sisymbrieae subtribe Brayinae, Platycraspedum in the Lepidieae, Neomartinella in the Arabideae, and Chalcanthus in the Brassiceae. As discussed above, he included in these suprageneric taxa many unrelated elements, and it is likely that the tribe might be unigeneric.

Members of the Eutremeae are glabrous or with simple trichomes and have white flowers, incumbent cotyledons, often palmately veined basal leaves, and a base chromosome number of $x=7$.

Tribe Thlaspideae. The tribe consists of 26 species in seven genera restricted to Europe and southwestern Asia. It includes Alliaria (2 spp.), Graellsia Boiss. (8 spp.), Pachyphragma (DC.) Rchb. (1 sp.), Parlatoria Boiss. (2 spp.), Peltaria Jacq. (4 spp.), Pseudocamelina (Boiss.) N. Busch (3 spp.), and Thlaspi s.str. (6 spp.). Sobolewskia M. Bieb. (4 spp.), which has not yet been surveyed, might belong to this tribe.

As indicated above, Thlaspi s.str. is unrelated to the ca. 90 species previously assigned to it, and the vast majority of those belong to the unrelated Noccaea (ca. 85 spp.) and immediate allies. Extensive molecular studies (Koch and Mummenhoff 2001; Mummenhoff et al. 1997a, 1997b, 2001b; Beilstein et al. 2006) defined the boundaries of this tribe.

Members of the Thlaspideae are characterized by having simple or no trichomes, striate or coarsely reticulate seeds, entire cauline leaves, often palmately veined basal leaves, and a base chromosome number of $x=7$.

Tribe Noccaeeae. This new tribe includes about three genera and some 85 species all except for five New World species of Noccaea (one each in Patagonia and Mexico and three 
in the United States and Canada) are distributed in Eurasia and northern Africa. The extensive molecular studies [for summaries see Koch (2003), Koch and Al-Shehbaz (2004), and the discussion above on Thlaspi] support the clear distinction between Noccaea and Thlaspi. However, all of the segregates of Thlaspi by Meyer (1973, 1979) group with Noccaea in a well-supported clade, and only a few of his ten segregates might deserve recognition (Koch 2003). These include Neurotropis (DC.) F.K. Mey., only part of Microthlaspi F.K. Mey., and the remaining segregates should perhaps best treated as synonyms of Noccaea. Microthlaspi was subjected to extensive molecular studies (Koch et al. 1998, Koch and Hurka 1999, Koch and Bernhardt 2004).

The Noccaeeae are characterized by having glabrous, often perennial plants with angustiseptate fruits, smooth seeds, often auriculate cauline leaves, and a base chromosome number of $x=7$.

Tribe Hesperideae. This unigeneric tribe consists of Hesperis (46 spp.), a genus centered in the Middle East and Europe, with poor representations in northern Africa and central Asia.

As delimited by Prantl (1891), Hayek (1911), and Schulz (1936), the Hesperideae included many other genera, none of which have uniseriate glands. By contrast, de Candolle (1821a, b) placed Hesperis in the Sisymbrieae. In the study of Beilstein et al. (2006), Hesperis and 20 other genera formed an unresolved polytomy with only $68 \%$ support. However, that polytomy included four, highly supported ( $97-100 \%$ bootstrap) subclades recognized herein as the tribes Hesperideae, Anchonieae, Euclidieae, and Chorisporeae.

The tribe is readily distinguished from the rest of the Brassicaceae by having stalked glands with uniseriate stalks terminated with a unicellular gland. Multicellular stalked glands occur in the Chorisporeae and Anchonieae, but in these tribes the stalks are multiseriate and the glands are multicellular. The Hesperideae includes biennial or perennial plants with simple and/or forked trichomes, tardily dehiscent siliques, decurrent stigma lobes, and base chromosome numbers of $x=6-10$. Hesperis is much in need of thorough systematic and phylogenetic studies.

Tribe Anchonieae. The Anchonieae include some 12 genera and about 130 species distributed primarily in Eurasia and eastern and northern Africa, with only four species of Parrya R.Br. (ca. 34 spp.) in North America. In addition, the tribe includes Anchonium DC. (2 spp.; Jacquemoud, 1984), Bunias L. (3 spp.), Clausia Korn.-Trotzky (6 spp.), Dontostemon (11 spp.), Iskandera N. Busch (2 spp.), Matthiola R.Br. (48 spp.; see Gowler, 1998), Microstigma Trautv. (3 spp.), Sterigmostemum M. Bieb. (7 spp.; Jacquemoud, 1988), and the monotypic Zerdana Boiss. (Appel and AlShehbaz 2003). Oreoloma Botsch. (3 spp.) and Pseuoclausia Popov (10 spp.) should perhaps be united with Sterigmostemum and Clausia, respectively. The exact position of Dontostemon and Bunias with the rest of the Anchonieae was not fully resolved in Beilstein et al. (2006), and further studies are needed to firmly establish that. Phylogenetic studies of this tribe are in progress (Warwick et al., pers com.).

Excluding Chorispora R.Br. ex DC. and Diptychocarpus Trautv., genera of the Anchonieae have multicellular-multiseriate glands. Schulz (1936) placed all such genera, along with a highly heterogeneous assemblage of others, in the Hesperideae and Matthioleae. These two tribes were later combined by Janchen (1942) as the Hesperideae and by Al-Shehbaz (1988b) as the Anchonieae. However, as delimited by all these authors, as well as Prantl (1891) and Hayek (1911), none of them was monophyletic.

Although Parrya was not included in Beilstein et al. (2006), Yue et al. (in press) showed that it should be assigned to the same clade including such glands. Parrya, Dontostemon, and Matthiola include species with or without multicellular glands, and it is likely that the absence of such gland occurred independently. 
In addition to the multicellular-multiseriate glands, members of the Anchonieae also have branched trichomes, often strongly 2-lobed stigmas, erect sepals, and a base chromosome number of $x=7$, though Matthiola show reductional aneuploid series to $x=5$ and increase to $x=8$.

Tribe Euclidieae. The tribe is primarily Eurasian and northern and eastern African, and only seven of 17 species of Braya Sternb. \& Hoppe are North American. It consists of about 25 genera and over 150 species. In addition to Braya, it includes Desideria Pamp. (12 spp.), Euclidium R. Br. (1 sp.), Malcolmia R.Br. (32 spp.), Neotorularia Hedge \& J. Léonard (11 spp.), Rhammatophyllum O.E. Schulz (10 spp.), Shangrilaia Al-Shehbaz, J.P. Yue \& H. Sun (1 sp.), Solms-laubachia Muschl. (9 spp.), and Tetracme Bunge (10 spp.). According to Mitchell and Heenan (2000) and Koch (2003), the New Zealandic Notothlaspi Hook.f. (2 spp.) might belong here too, but the genus was not included in Beilstein et al. (2006). On the basis of morphological grounds, several genera probably belong to the Euclidieae, but they need to be studied using molecular data. Among these are Diceratella Boiss. (11 spp.), Leiospora (C.A. Mey.) F. Dvorák (6 spp.), Parolinia Webb (5 spp.), Maresia Pomel (3 spp.), Morettia DC. (3 spp.), Cryptospora Kar. \& Kir. (3 spp.), Dilophia Thomson (2 spp.), Cithareloma Bunge (2 spp.), and the monotypic Anastatica L., Atelanthera Hook.f. \& Thomson, Eremobium Boiss., Leptaleum DC., Notoceras R.Br., and Vesleskya Opiz. Phylogenetic studies addressing relationships in this tribe are in progress (Warwick et al., pers com.).

This tribe showed $99 \%$ bootstrap support in Beilstein et al. (2006), and it exhibited internal differentiation into two, well-resolved clades represented by the larger genera Braya and Malcolmia. Warwick et al. (2004a) showed that both Neotorularia and Sisymbriopsis Botsch. \& Tzvelev (5 spp.) are polyphyletic, and some of their component species need to be re-assigned to other genera or placed in independent ones.
The tribe is characterized by the lack of multicellular glands and the presence of incumbent cotyledons, erect sepals, branched trichomes (rarely simple or absent), entire or 2lobed stigmas, often terete to 4-angled siliques or silicles, and a base chromosome number of $x=7$, though $x=8$ is less common.

Tribe Chorisporeae. This exclusively Asian tribe consists of Chorispora (11 spp.) and Diptychocarpus (1 sp.). It formed a welldefined clade in Beilstein et al. (2006), with $100 \%$ bootstrap support.

Chorispora was placed by de Candolle (1821a, 1821b) with Cakile, Rapistrum, and Cordylocarpus Desf. in the tribe Cakileae, but it is generally agreed (e.g. Hayek 1911, Schulz 1936) that the last three genera belong to the Brassiceae.

The Chorisporeae is characterized by the lack of branched trichomes and the presence of connivent stigmas, multicellular-mutiseriate glands, moniliform fruits breaking into 1seeded, corky segments, erect sepals forming a closed calyx, and a base chromosome number of $x=7$, though $x=9$ was reported in some Chorispora.

Tribe Heliophileae. This tribe is restricted to South Africa and presently consists of 82 species of Heliophila. Six genera were previously assigned to the Heliophileae (Appel and Al-Shehbaz 1997), but they have recently been united by Al-Shehbaz and Mummenhoff (2005) and Mummenhoff et al. (2005) with Heliophila s.1. Beilstein et al. (2006) included only one species of Heliophila, but it appeared in a clade of its own in the overall polytomy of the family. The genus formed a monophyletic clade in the work of Mummenhoff et al. (2005), and their results are taken to support the placement of the genus in its own tribe.

It is not known if the Heliophileae would remain unigeneric or if it would also include the South African Chamira Thunb., the single species of which, C. circaeoides (L.f.) Zahlbr., has double conduplicate, persistent cotyledons larger than the leaves of the plant, and typically spurred calyx. Hayek (1911) and Schulz (1936) placed Chamira and Heliophila 
in separate tribes, but de Candolle (1821a, b) placed them in the Heliophileae.

The tribe is easily distinguished by having diplecolobal cotyledons, a feature that has evolved independently in three Australian species of Lepidium (see above). All species of the tribe are either glabrous or with simple trichomes, and the majority have appendaged petals and/or staminal filaments and "extrafloral nectaries" (termed stipules by Marais 1966) at the base of pedicels and/or leaves. Chromosome numbers are known for only four species of Heliophila, all of which have $n=10$.

Tribe Cochlearieae. This unigeneric tribe consists of Cochlearia (21 spp., including five of Ionopsidium). The genus, which is distributed primarily in Europe, northwestern Africa, and northern North America and Asia, was subjected to extensive molecular studies (Koch 2002; Koch et al. 1996, 1999b, 2003b), and it appeared in a basal polytomy of the family (Koch 2003). Although Beilstein et al. (2006) studied only one species of Ionopsidium, and it too appeared in a clade of its own in the overall basal polytomy of the family, the results of Koch and colleagues are taken to support the recognition of this unigeneric tribe.

Schulz (1936) place Cochlearia in the tribe Lepidieae subtribe Cochleariinae, but he also included genera assigned herein to the Eutremeae (Platycraspedum), Halimolobeae (Poliophyton O.E. Schulz, now Halimolobos), Lepidieae (Stroganowia, now Lepidium), and six other genera that have not yet been studied molecularly.

The Cochlearieae are distinguished by being glabrous plants with rosulate, undivided basal leaves, often sessile cauline leaves, white petals, terete or angustiseptate silicles, biseriate seeds, entire stigmas, ebracteate racemes, and a base chromosome numbers of $x=6$ or 7 .

Tribe Iberideae. As presently delimited, this tribe consists only of Iberis (ca. 27 spp.), and it is distributed primarily in Europe, with fewer species in northwestern Africa, Turkey, and southwestern and central Asia. The single species studied by Beilstein et al. (2006) formed a clade of its own in the overall polytomy of the family. Because of the distinctive morphology of Iberis (see below), the genus is placed herein in a tribe of its own.

Schulz (1936) placed the genus in the tribe Lepidieae subtribe Iberidinae, but he also included genera now assigned to the Physarieae (Dithyrea) and Aethionemeae (Moriera), as well as five other genera of unknown affinities.

The Iberideae are distinguished by having strongly angustiseptate, 2-seeded fruits, corymbose infructescences, simple trichomes or glabrous, and often zygomorphic flowers with strongly unequal pairs of petals, especially in the outer flowers of the corymb.

Other genera. As many as 135 smaller or medium-sized genera, representing only about 400 species of Brassicaceae, remain to be studied for at least one molecular marker. Furthermore, the systematic position of some of the genera already sampled remain unresolved. Both Megacarpaea DC. (9 spp.) and Biscutella (53 spp.) were placed in the Lepidieae by Schulz, but it is doubtful if they belong to that tribe. Indeed, the latter genus fell outside this alliance in the survey of Beilstein et al. (2006), but its position with regards to the other groups still needs to be firmly established.

Schulz (1936) recognized the South American tribe Menonvilleae, which included Menonvillea DC. (24 spp.) and Cremolobus DC. (8 spp.). It is not known if these two genera merit the placement in their own tribe.

Members of the primarily Chinese Yinshania (13 spp.) have compound leaves and grow in wet habitats (Koch and Al-Shehbaz 2000), as do most members of the Cardamineae, but in the overall phylogeny of the family (Koch 2003), Yinshania appears to be more closely related to the Camelineae than to the Cardamineae. The genus needs to be studied to check if it belongs to the tribe Smelowskieae, as these taxa show significant similarities in leaf, fruit, and trichome morphology. 


\section{Problematic groups}

As discussed above, the Brassiceae, Schizopetaleae, and Arabis are taxa with serious problems relating to generic boundaries. More problematic is the delimitation of taxa the evolutionary history of which involved extensive polyploidy, hybridization, and apomixis. Polyploidy and hybridization have been well documented in Draba (Brochmann 1992; Brochmann et al. 1992 and references therein; Widmer and Baltisberger 1999a, b; Koch and Al-Shehbaz 2002; Scheen et al. 2002; Beilstein and Windham 2003; Grundt et al. 2004), Cardamine (Neuffer and Janche 1997; Urbanska et al. 1997; Franzke et al. 1998; Franzke and Mummenhoff 1999; Franzke and Hurka 2000; Lihová et al. 2000; Bleeker et al. 2002a; Marhold et al. 2002a, 2002b, 2004), and Lepidium (Lee et al. 2002; Mummenhoff et al. 2001a, 2004 and references therein). It is likely that these two phenomena influenced the evolution of all major genera of the family. The subject is discussed in further detail in the paper by Marhold and Lihova (2006) in this issue.

Most of the discussion below will focus on Boechera, a genus distributed primarily in the western United States and Canada. Until recently, Boechera was considered as part of Arabis (Rollins 1993), but molecular studies (summarized in Al-Shehbaz 2003b) show that the two genera are not closely related and placed herein in different tribes. The pioneering cytological and embryological studies by Böcher (1951, 1969, and references therein) firmly established apomixis in the genus. The molecular basis of apomixis is being investigated in several Boechera species. The aim is to apply the knowledge gained from apomictic plants in the potential development of easily propagated apomictic crop plants (Hoisington et al. 1999, van Dijk and van Damme 2000).

Boechera consists of over 60 species of sexual diploids $(2 n=14)$ and about 40 apomictic triploids $(3 n=21) \quad$ (Windham, pers. com.). Aneuploidy was reported in the $B$. holboellii species complex (Böcher 1951, Roy
1995, Sharbel and Mitchell-Olds 2001), and recent studies involving DNA sequences of microsatellites markers (Sharbel et al. 2004) suggest that aneuploidy involves non-recombining $\mathrm{B}$ chromosomes that may also play a role in apomixis.

Although Boechera (as Arabis) was subjected to extensive taxonomic and cytological studies (Rollins 1941, 1983, 1993; Mulligan 1996), neither hybridization nor apomixis were addressed. Recent molecular studies (Roy 2001; Sharbel and Mitchell-Olds 2001; Dobeš et al. 2003, 2004a, 2004b; Koch et al. 2003c; Sharbel et al. 2004) focused primarily on $B$. stricta (=Arabis drummondii), B. holboellii (Hornem.) A. Löve \& D. Löve, and their "alleged" triploid apomictic hybrid, $B . \times d i$ varicarpa (A. Nelson) A. Löve \& D. Löve. However, the genus appears to be far more complicated than what had been suggested thus far.

As indicated by Windham et al. (2004), the first serious problem in the study of Boechera is taxon identity, and erroneous determinations in the holdings of the major herbaria can be as high as $40 \%$. Hybridization appears to have played a far more major role in the evolution of the genus than was suggested by Rollins (1983) and Mulligan (1996). Preliminary studies (Windham, pers. com.) strongly suggest that $B$. stricta, which is the most widespread species of the genus, hybridized with almost every diploid species with which its range overlapped. It appears that in all cases, the resulting hybrids often become stabilized apomictic triploids, distinct morphologically and isolated reproductively from both parents. There seems to be evidence that the triploid hybrids also involved three parental species, and that those are also fixed through apomixis. As suggested by Dobeš et al. (2004), Pleistocene differentiation in Boechera was greatly influenced by alternating glacial and interglacial cycles. Therefore, the genus has undergone rapid bursts of reticulate evolution, which produced a mind-boggling array of forms that have blurred species boundaries. 


\section{Genomics and development}

There is no doubt that once a clearer picture on the overall phylogeny of the family is obtained, less emphasis should be paid to large-scale surveys such as that of Beilstein et al. (2006). Far more exciting is comparative genomic studies that focus on evolution within complex groups.

The pioneering studies of Lagercrantz and Lydiate (1996) and Lagercrantz (1998) showed that the genomes within the cultivated Brassica underwent extensive triplications of large genomic regions accompanied by chromosomal rearrangements. These led to the conclusion that so-called "diploid" species in the genus, such as $B$. nigra $(n=8), B$. oleracea $(n=9)$ and $B$. rapa $(n=10)$ represent ancestral hexaploids. In fact, chromosome triplication has recently been documented in the entire tribe Brassiceae (Lysak et al. 2005). The recent advancement in genome research and its very promising role in understanding the evolutionary history of the family are covered in the accompanying paper by Lysak and Lexer (2006).

As indicated by Kellogg and Bennetzen (2004 and references therein), it appears that the entire Brassicaceae evolved after the genome duplication of its ancestors. This has also been recently suggested by Schranz and Mitchell-Olds (2005). What is needed are studies of genome size throughout basal Aethionema to determine if indeed the so-called "diploid" species with $n=7$ and 8 are ancient tetraploids.

Although genome size is highly variable in the Brassicaceae (Johnston et al. 2005) and useful to a certain extent, it becomes a far more valuable tool when combined with studies involving the determination of chromosome numbers, chromosome painting, and comparative genomics. It is rather intriguing to find two species of the same genus, such as Physaria bellii G.A. Mulligan $(n=4)$ and $P$. didymocarpa (Hook.) A. Gray $(n=12)$, to have a similar genome size (Lysak, pers. com.). Studies to understand the evolution of the wide array of chromosomal numbers and ploidy levels found in Physaria are in progress (Fuentes-Soriano, pers. com.). Fuller understanding of the developmental genetics of various structures will have a major impact in phylogenetic and systematics studies in the Brassicaceae. For example, much taxonomic emphasis has been placed on the arrangement of flowers in racemes or on solitary pedicels originating from the basal rosette. We now know that a few genes, including $L E A F Y$, control the development of rosette instead of raceme flowering in the Brassicaceae (Shu et al. 2000, Baum 2002, Yoon and Baum 2004), and several genera (e.g. Leavenworthia, Selenia) can have both types of flowering on the same plant. The effects of various genes on the development of flower and fruit in the family are covered by John Bowman (2006) and Günter Theissen (2006) in this issue.

\section{Taxonomic considerations}

Of the 49 infrafamilial taxa (19 tribes and 30 subtribes) recognized by Schulz (1936), eight tribes (Alysseae, Arabideae, Brassiceae, Euclidieae, Heliophileae, Hesperideae, Lepidieae, Sisymbrieae) are accepted herein. Seven tribes are proposed as new, and two (Physarieae, Descurainieae) were recognized previously (e.g. Schulz 1936) as subtribes. The bibliographical citation and type genera of all tribes are given. Contrary to the listing of Hayek (1911), Schulz (1936), and Al-Shehbaz (1984), the tribes proposed by de Candolle first appeared in April (de Candolle 1821a) instead of late May (de Candolle 1821b). A synopsis, keys, and complete tribal assignment of all genera of the Brassicaceae are being prepared for a separate publication.

Tribe Aethionemeae Al-Shehbaz, Beilstein \& E.A. Kellogg, trib. nov. Type genus: Aethionema R.Br. in W. T. Aiton, Hortus Kew. ed. 2, 4: 80. 1812.

Herbae suffrutices, perennes vel annuae, glabrae saepe glaucae; folia integra, saepe carnosa, sessilia vel breviter petiolata, basi articulata; racemi ebracteati; filamenta 
plerumque alata, dentata vel integra; ovula 18; fructus siliculae, valde compressi, angustiseptati, biloculares oligospermi dehiscentes vel uniloculares monospermi indehisentes.

Tribe Camelineae DC., Mém. Mus. Hist. Nat. 7(1): 239. 1821. Type genus: Camelina Crantz, Stirp. Austr., ed. 1, 1: 17. 1762.

Syn.: Erysimeae Dumort., Fl. Belg. 123. 1827; Capselleae Horan., Char. Ess. Fam.: 170. 1847; Turriteae Buchenau, Fl. Nordwestdeut. Tiefebene: 258. 1894.

Tribe Boechereae Al-Shehbaz, Beilstein \& E.A. Kellogg, trib. nov. Type genus: Boechera A. Löve \& D. Löve, Bot. Not. 128: 513. 1975, publ. 1976.

Herbae perennes vel annuae, pilis simplicibus vel multifurcatis; folia integra vel dentata, sessilia vel breviter petiolata, basi saepe auriculata; racemi ebracteati; petala alba vel rosea, ovula 2 vel numerosa; fructus siliquae vel rarissime siliculae, latiseptati vel teretes; semina uniseriata vel biseriata, nonmucilaginosa; cotyledones accumbentes vel incumbentes.

Tribe Halimolobeae Al-Shehbaz, Beilstein \& E.A. Kellogg, trib. nov. Type genus: Halimolobos Tausch, Flora (Regensburg) 19: 410. 1836.

Herbae perennes vel annuae, pilis simplicibus vel furcatis; folia integra vel rarissime dentata, sessilia, basi auriculata vel exauriculata; racemi bracteati vel ebracteati; petala alba vel rosea; ovula numerosa; fructus siliquae vel siliculae, pili furcati praediti vel rarissime glabri, angustiseptati vel teretes; semina uniseriata vel biseriata, mucilaginosa; cotyledones incumbentes.

Tribe Physarieae B.L. Rob., Synop. Fl. N. Amer. 1: 100. 1895. Type genus: Physaria (Nutt.) A. Gray, Gen. Illustr. 1: 162. 1848.

Syn.: Schizopetaleae subtr. Physariinae Prantl in Engler \& Prantl, Nat. Pflanzenfam. III. 2: 154. 1891; Schizopetaleae subtr. Lyrocarpinae Hayek, Beih. Bot. Centralbl. 27: 313. 1911.

Tribe Cardamineae Dumort., Fl. Belg.: 124. 1827. Type genus Cardamine L., Sp. P1. 2: 654. 1753.
Syn.: Selenieae Torr. \& A. Gray, Fl. N. Amer. 1(1): 99. 1838; Nasturtieae Caruel in Parl., Fl. Ital. 9: 726. 1893.

Tribe Lepidieae DC., Mém. Mus. Hist. Nat. 7(1): 240. 1821 (as Lepidineae). Type genus: Lepidium L., Sp. Pl. 2: 643. 1753.

Syn.: Cardarieae Caruel in Parl., Fl. Ital. 9: 658. 1893.

Tribe Alysseae DC., Mém. Mus. Hist. Nat. 7(1): 231. 1821. Type genus Alyssum L., Sp. Pl. 2: 650.1753.

Syn.: Clypeoleae Webb \& Berthel., Hist. Nat. Iles Canaries 3(2,1): 89. 1837.

Tribe Descurainieae Al-Shehbaz, Beilstein \& E.A. Kellogg, trib. nov. Type genus: Descurainia Webb \& Berthel., Hist. Nat. Iles Canaries 3(1): 72. 1836.

Syn.: Lepidieae subtr. Tropidocapinae Hayek, Beih. Bot. Centralbl. 27: 307. 1911; Sisymbrieae subtr. Descurainiinae O.E. Schulz in Engler \& H. Harmsl, Nat. Pflanzenfam., ed. 2. 17B: 649. 1936, nom. invalid.

Herbae suffrutices, perennes vel annuae, pilis simplicibus vel multifurcatis; folia bi- vel tripinnatisecta, petiolata, basi nonauriculata; racemi saepe ebracteati; petala flava, rarissime alba; ovula numerosa; fructus siliquae vel siliculae, glabri, teretes; semina uniseriata vel biseriata, mucilaginosa; cotyledones incumbentes.

Tribe Smelowskieae Al-Shehbaz, Beilstein \& E.A. Kellogg, trib. nov. Type genus: Smelowskia C. A. Mey. in Ledeb., Icon. Pl. 2: 17. 1830.

Herbae suffrutices, perennes vel annuae, pilis simplicibus vel multifurcatis; folia 1-3pinnatisecta, petiolata, basi nonauriculata; racemi ebracteati vel bracteati; petala flava, alba vel purpurea; ovula numerosa; fructus siliquae vel siliculae, glabri, teretes, latiseptates vel angustiseptates; semina uniseriata vel biseriata, nonmucilaginosa; cotyledones incumbentes vel accumbentes.

Tribe Arabideae DC., Mém. Mus. Hist. Nat. 7(1): 229. 1821. Type genus: Arabis L., Sp. Pl. 2: 664. 1753. 
Tribe Brassiceae DC., Mém. Mus. Hist. Nat. 7(1): 242. 1821. Type genus: Brassica L., Sp. Pl. 2: 666. 1753.

Syn.: Cakileae DC., Mém. Mus. Hist. Nat. 7(1): 236. 1821(as Cakilineae); Velleae DC., Mém. Mus. Hist. Nat. 7(1): 243. 1821; Psychineae DC., Mém. Mus. Hist. Nat. 7(1): 244. 1821; Zilleae DC., Mém. Mus. Hist. Nat. 7(1): 244. 1821; Raphaneae DC., Mém. Mus. Hist. Nat. 7(1): 245. 1821; Erucarieae DC., Mém. Mus. Hist. Nat. 7(1): 246. 1821.

Tribe Schizopetaleae R.Br. in Barnéoud, Ann. Mag. Nat. Hist. 16: 68. 1845. Type genus: Schizopetalon Sims., Bot. Mag. t. 2379. 1823.

Syn.: Thelypodieae Prantl in Engler \& Prantl, Nat. Pflanzenfam. III. 2: 155. 1891; Stanleyeae B.L. Robins., Synop. Fl. N. Amer. 1: 105. 1895; Pringleeae Hayek, Beih. Bot. Centralbl. 27: 315. 1911; Romanschulzieae O.E. Schulz in Engler \& Harms, Nat. Pflanzenfam., ed. 2. 17B: 298. 1936, nom. invalid.; Streptantheae O.E. Schulz in Engler \& Harms, Nat. Pflanzenfam., ed. 2. 17B: 300. 1936, nom. invalid.

Tribe Sisymbrieae DC., Mém. Mus. Hist. Nat. 7(1): 237. 1821. Type genus: Sisymbrium L., Sp. Pl. 2: 657. 1753.

Tribe Isatideae DC., Mém. Mus. Hist. Nat. 7(1): 241. 1821. Type genus: Isatis L., Sp. Pl. 2: 670. 1753.

Syn.: Myagreae Caruel in Parl., Fl. Ital. 9: 1029. 1893.

Tribe Eutremeae Al-Shehbaz, Beilstein \& E.A. Kellogg, trib. nov. Type genus: Eutrema R.Br., Chlor. Melvill. 9. 1823.

Herbae perennes vel annuae, glabrae vel rarissime pilosae, pilis simplicibus; folia integra, basalia longe petiolata, saepe palmativenosa; folia caulina sessilia vel petiolata, auriculata vel nonauriculata; petala alba vel rosea; fructus siliquae vel siliculae, glabri, teretes, quadrangulares vel compressi; semina uniseriata; cotyledones incumbentes.

Tribe Thlaspideae DC., Mém. Mus. Hist. Nat. 7(1): 234. 1821. Type genus: Thlaspi L., Sp. Pl. 2: 645. 1753.

Syn.: Peltarieae Caruel in Parl., Fl. Ital. 9: 1043. 1893.
Tribe Noccaeeae Al-Shehbaz, Beilstein \& E.A. Kellogg, trib. nov. Type genus: Noccaea Moench, Meth. Suppl. 89. 1802.

Herbae perennes vel annuae, glabrae vel rarissime pilosae, pilis simplicibus; folia integra, sessilia, saepe auriculata; petala alba vel rosea; ovula 4 vel numerousa; fructus siliculae, valde compressi, glabri, angustiseptati; semina uniseriata, laevia, nonmucilaginosa.

Tribe Hesperideae Prantl in Engler \& Prantl, Nat. Pflanzenfam. III. 2: 154. 1891. Type genus: Hesperis L., Sp. Pl. 2: 663. 1753.

Tribe Anchonieae DC., Mém. Mus. Hist. Nat. 7(1): 242. 1821. Type genus: Anchonium DC., Mém. Mus. Hist. Nat. (Paris) 7(1): 242. 1821.

Syn.: Buniadeae DC., Mém. Mus. Hist. Nat. 7(1): 245. 1821; Matthioleae O.E. Schulz in Engler \& Harms, Nat. Pflanzenfam., ed. 2. 17B: 557. 1936, nom. invalid.

Tribe Euclidieae DC., Mém. Mus. Hist. Nat. 7(1): 236. 1821. Type genus: Euclidium R.Br. in W.T. Aiton, Hortus Kew., ed. 2, 4: 74. 1812.

Syn.: Anastaticeae DC., Mém. Mus. Hist. Nat. 7(1): 236. 1821.

Tribe Chorisporeae Ledeb., C.A. Mey. \& Bunge, Fl. Altaic. 3: 104. 1831. Type genus: Chorispora R.Br. ex DC., Mém. Mus. Hist. Nat. (Paris) 7(1): 237. 1821.

Tribe Heliophileae DC., Mém. Mus. Hist. Nat. 7(1): 246. 1821. Type genus Heliophila L., Sp. Pl. ed. 2: 926. 1763.

Syn.: Brachycarpaeae DC., Mém. Mus. Hist. Nat. (Paris) 7(1): 247. 1821.

Tribe Cochlearieae Buchenau, Fl. Nordwestdeut. Tiefebene: 245. 1894. Type genus: Cochlearia L., Sp. Pl. 2: 647. 1753.

Syn.: Sinapeae subtr. Cochleariinae Prantl in Engler \& Prantl, Nat. Pflanzenfam. III. 2: 163. 1891.

Tribe Iberideae Webb \& Berthel., Hist. Nat. Iles Canaries 3(2,1): 92. 1837. Type genus: Iberis L., Sp. Pl. 2: 648. 1753.

Syn.: Lepidieae subtr. Iberidinae Hayek, Beih. Bot. Centralbl. 27: 315. 1911.

The authors are grateful to Oliver Appel, C. Donovan Bailey, James Beck, Sara Fuentes- 
Soriano, Barbara Goodson, Herbert Hurka, Marcus Koch, Michael Mayer, Marck Menke, Thomas Mitchell-Olds, Klaus Mummenhoff, Steve L. O'Kane, Jr., Robert A. Price, Nicholas J. Turland, Suzanne I. Warwick, Michael Windham, and Jipei Yue for advice and fruitful discussions. We are much indebted to Suzanne I. Warwick for her critical review of the manuscript and to Henk van der Werff for correcting the Latin.

\section{References}

Akeroyd J. R. (1993) Arabis. In: Tutin T. G. et al. (eds.) Fl. Europaea, 2nd edn., vol. 1. University Press, Cambridge, pp. 352-356.

Al-Shehbaz I. A. (1973) The biosystematics of the Genus Thelypodium Cruciferae. Contr. Gray Herb. 204: 3-148.

Al-Shehbaz I. A. (1984) The tribes of Cruciferae (Brassicaceae) in the southeastern United States. J. Arnold Arbor. 65: 343-373.

Al-Shehbaz I. A. (1985a) The genera of Thelypodieae (Cruciferae; Brassicaceae) in the southeastern United States. J. Arnold Arbor. 66: 95-111.

Al-Shehbaz I. A. (1985b) The genera of Brassiceae (Cruciferae; Brassicaceae) in the southeastern United States. J. Arnold Arbor. 66: 279-351.

Al-Shehbaz I. A. (1986) The genera of Lepidieae (Cruciferae; Brassicaceae) in the southeastern United States. J. Arnold Arbor. 67: 265-311.

Al-Shehbaz I. A. (1988a) The genera of Arabideae (Cruciferae; Brassicaceae), the southeastern United States. J. Arnold Arbor. 69: 85-166.

Al-Shehbaz I. A. (1988b) The genera of Anchonieae (Hesperideae) (Cruciferae; Brassicaceae), the southeastern United States. J. Arnold Arbor. 69: 193-212.

Al-Shehbaz I. A. (1988c) The genera of Sisymbrieae (Cruciferae; Brassicaceae), the southeastern United States. J. Arnold Arbor. 69: 213-237.

Al-Shehbaz I. A. (1989) Systematic and phylogeny of Schizopetalon (Brassicaceae). Harvard Pap. Bot. 1: 10-46.

Al-Shehbaz I. A. (2003a) A synopsis of Tropidocarpum (Brassicaceae). Novon 13: 392-395.

Al-Shehbaz I. A. (2003b) Transfer of most North American species of Arabis to Boechera (Brassicaceae). Novon 13: 381-391.

Al-Shehbaz I. A. (2005) Nomenclatural notes on Eurasian Arabis (Brassicaceae). Novon 15: 519524.
Al-Shehbaz I. A., Mummenhoff K. (2005) Transfer of the South African genera Brachycarpaea, Cycloptychis, Schlechteria, Silicularia, and Thlaspeocarpa to Heliophila (Brassicaceae). Novon 15: 385-389.

Al-Shehbaz I. A., O'Kane S. L. Jr. (2002a) Taxonomy and phylogeny of Arabidopsis (Brassicaceae). In: Somerville C. R., Meyerowitz E. M. (eds.) The Arabidopsis Book, American Society of Plant Biologists, Rockville, MD, pp. doi/ 10.1199/tab.0001, http://www.aspb.org/publications/arabidopsis/.

Al-Shehbaz I. A., O'Kane S. L. Jr. (2002b) Lesquerella is united with Physaria (Brassicaceae). Novon 12: 319-329.

Al-Shehbaz I. A., Price R. A. (1998) Delimitation of the genus Nasturtium (Brassicaceae). Novon 8: $124-126$.

Al-Shehbaz I. A., Price R. A. (2001) The Chilean Agallis and Californian Tropidocarpum (Brassicaceae) are congeneric. Novon 11: 292-293.

Al-Shehbaz I. A., Warwick S. I. (2006a) A synopsis of Smelowskia (Brassicacae). Bot. J. Linn. Soc. (in press).

Al-Shehbaz I. A., Warwick S. I. (2006b) A synopsis of Eutrema (Brassicacae). Harv. Papers Bot. (in press).

Al-Shehbaz I. A., Mummenhoff K., Appel O. (2002) Cardaria, Coronopus, and Stroganowia are united with Lepidium (Brassicaceae). Novon 12: 5-11.

Al-Shehbaz I. A., O'Kane S. L. Jr., Price R. A. (1999) Generic placement of species excluded from Arabidopsis (Brassicaceae). Novon 9: 296-307.

Anderson J. K., Warwick S. I. (1999) Chromosome number evolution in the tribe Brassiceae (Brassicaceae): evidence from isozyme umber. Pl. Syst. Evol. 215: 255-285.

Appel O., Al-Shehbaz I. A. (1997) Re-evaluatuin of tribe Heliophileae (Brassicaceae). Mitt. Inst. Allg. Bot. Hamburg 27: 85-92.

Appel O., Al-Shehbaz I. A. (2003) Cruciferae. In: Kubitzki K., Bayer C. (eds.) The families and genera of vascular plants. Springer, Berlin, pp. 75-174.

Bailey C. D. (2001) Systematics of Sphaerocardamum (Brassicaceae). Ph.D. dissertation, Cornell University, Ithaca. $180 \mathrm{pp}$.

Bailey C. D., Doyle J. J. (1999) Potential phylogenetic utility of the low-copy nuclear gene pistillata in dicotyledonous plants: comparison to 
nrDNA ITS and $\operatorname{trn} \mathrm{L}$ intron in Sphaerocardamum and other Brassicacae. Molec. Phylogenet. Evol. 13: 20-30.

Bailey C. D., Price R. A., Doyle J. J. (2002) Systematics of the halimolobine Brassicaceae: Evidence from three loci and morphology. Syst. Bot. 27: 318-332.

Barnéoud J. M. (1845) Observations on the group Schizopetaleae of the family Cruciferae. Ann. Mag. Nat. Hist. 16: 66-68.

Baum D. A. (2002) Identifying the genetic causes of phenotypic evolution: a review of experimental strategies. In: Cronk Q. C. B., Bateman R. M., Hawkins J. A. (eds.) Developmental genetics and plant evolution. Taylor and Francis, London, pp. 493-507.

Beilstein M. A., Szymanski D. (2004) Cytoskeletal requirements during Arabidopsis trichome development. In: Hussey P. J. (ed.) The plant cytoskeleton in cell differentiation and development. Blackwell, Cambridge, pp. 266-289.

Beilstein M. A., Windham M. D. (2003) A phylogenetic analysis of western North American Draba (Brassicaceae) based on nuclear ribosomal DNA sequences from the ITS region. Syst. Bot. 28: 584-592.

Beilstein M. A., Al-Shehbaz I. A., Kellogg E. A. (2006) Brassicaceae phylogeny and trichome evolution. Amer. J. Bot. (in press).

Bleeker W., Franzke A., Pollmann K., Brown A. H. D., Hurka H. (2002a) Phylogeny and biogeography of southern hemisphere high-mountain Cardamine species (Brassicaceae). Austral. Syst. Bot. 15: 575-581.

Bleeker W., Huthmann M., Hurka H. (1999) Evolution of hybrid taxa in Nasturtium R.Br. (Brassicaceae). Folia Geobot. Phytotax. 34: 421-433.

Bleeker W., Weber-Sparenberg C., Hurka H. (2002b) Chloroplast DNA variation and biogeography in the genus Rorippa Scop. (Brassicaceae). Pl. Biol. 4: 104-111.

Böcher T. W. (1951) Cytological and embryological studies in the amphi-apomictic Arabis holboellii complex. Biol. Skr. 6: 1-59.

Böcher T. W. (1969). Further studies in Arabis holboellii and allied species. Bot. Tidsskr. 64: 141-161.

Bowmann J. L. (2006) Molecules and morphology: comparative developmental genetics of the Brassicaceae. Pl. Syst. Evol. 259: 199-215.
Bowman J. L., Brüggemann H., Lee J. Y., Mummenhoff K. (1999) Evolutionary changes in floral structure within Lepidium L. (Brassicaceae). Int. J. Pl. Sci. 160: 917-929.

Brochmann C. (1992) Polyploid evolution in Arctic-alpine Draba (Brassicaceae). Sommerfeltia Suppl. 4: 1-37.

Brochmann C., Stedje B., Borgen L. (1992) Gene flow across ploidal levels in Draba (Brassicaceae). Evol. Trends Pl. 6: 125-134.

Crespo M. B., Lledó M. D., Fay M. F., Chase M. W. (2000) Subtribe Vellinae (Brassiceae, Brassicaceae): a combined analysis of ITS nrDNA sequences and morphological data. Ann. Bot. 86: 53-62.

de Candolle A. P. (1821a) Mémoire sur la famille des Crucifères. Mém. Mus. Hist. nat. 7(1): 169-252.

de Candolle A. P. (1821b) Regni Vegetabilis Systema Natruralle, sive ordines, genera et species plantarum secundum methodi natrualis normas digestarum et descriptarum. vol. 2, Treuttel and Würtz, Paris, pp. 1-745.

Dinneny J. R., Yanofsky M. F. (2004) Drawing line and borders: how the dehiscent fruit of Arabidopsis is patterned. BioEssays 27: 42-49.

Dobeš C., Mitchell-Olds T., Koch M. (2003) Multiple hybrid formation in natural populations: concerted evolution of the internal transcribed spacer of nuclear ribosomal DNA (ITS) in North American Arabis divaricarpa (Brassicaceae). Molec. Biol. Evol. 20: 338-350.

Dobeš C., Mitchell-Olds T., Koch M. (2004a) Extensive chloroplast haplotype variation indicates Pleistocene hybridization and radiation of North American Arabis drummondii, A. ×divaricarpa, and A. holboellii (Brassicaceae). Mol. Ecol. 13: 349-370.

Dobeš C., Mitchell-Olds T., Koch M. (2004b) Intraspecific diversification in North American Boechera stricta ( = Arabis drummondii), Boechera $\times$ divaricarpa, and Boechera holboellii (Brassicaceae) inferred from nuclear and chloroplast molecular markers-an integrative approach. Amer. J. Bot. 91: 2087-2101.

Dudley T. R., Cullen J. (1965) Studies in the Old World Alysseae Hayek. Feddes Repert. 71: 218228.

Dvorák F. (1973) The importance of the indumentum for the investigation of evolutional relationship in family Brassicaceae. Österr. Bot. Zeit. 121: 155-164. 
Erdtman G. (1971) Pollen morphology and plant taxonomy. Hafner, New York.

Ferrandiz C. (2002) Regulation of fruit dehiscence in Arabidopsis. J. Exper. Bot. 53: 2031-2038.

Ferrandiz C., Liljegren S. J., Yanofsky M. F. (2000) Negative regulations of SHATTERPROOF genes by FRUITFUL during Arabidopsis fruit development. Science 289: 436-438.

Ferrandiz C., Pelaz S., Yanofsky M. F. (1999) Control of carpel and fruit development in Arabidopsis. Ann. Rev. Biochem. 68: 321-354.

Francisco-Ortega J., Fuertes-Aguilar J., GómezCampo C., Santos-Guerra A., Jansen R. K. (1999) Internal transcribed spacer sequence phylogeny of Crambe (Brassicaceae): molecular data reveal two Old World disjunctions. Molec. Phylogenet. Evol. 11: 361-380.

Francisco-Ortega J., Fuertes-Aguilar J., Kim S. C., Santos-Guerra A., Crawford D. J., Jansen R. K. (2002) Phylogeny of the Macaronesian endemic Crambe section Dendrocrambe (Brassicaceae) based on internal transcribed spacer sequences of nuclear ribosomal DNA. Amer. J. Bot. 89: 1984-1990.

Franzke A., Hurka H. (2000) Molecular systematics and biogeography of the Cardamine pratensis complex (Brassicaceae). Pl. Syst. Evol. 224: 213234.

Franzke A., Mummenhoff K. (1999) Recent hybrid speciation in Cardamine (Brassicaceae)-conversion of nuclear ribosomal ITS sequences in statu nascendi. Theor. Appl. Genet. 98: 831-834.

Franzke A., Pollmann K., Bleeker W., Kohrt R., Hurka H. (1998) Molecular systematics of Cardamine and allied genera (Brassicaceae): ITS and non-coding chloroplast DNA. Folia Geobot. Phytotax. 33: 225-240.

Fuentes-Soriano S. (2004) A taxonomic revision of Pennellia (Brassicaceae). Harvard Pap. Bot. 8: 173-202.

Galloway G. L., Malmberg R. L., Price R. A. (1998) Phylogenetic utility of the nuclear gene arginine decarboxylase: an example from Brassicaceae. Molec. Biol. Evol. 15: 1312-1320.

Gómez-Campo C. (1999) Taxonomy. In: GómezCampo C. (ed.) Biology of Brassica coenospecies. Elsevier, Amsterdam, pp. 3-32.

Gowler Z. R. (1998) A taxonomic revision of the genus Matthiola R.Br. (Cruciferae) and related genera. Ph.D. thesis, University of Edinburgh, Edinburgh.
Greuter W., McNeill J., Barrie F. R., Burdet H. M., Demoulin V., Filgueiras T. S., Nicolson D. H., Silva P. C., Skog J. E., Trehane P., Turland N. J., Hawksworth D. L. (2000) International Code of Botanical Nomenclature (St. Louis Cod). Koeltz Scientific Books, Königstein, Germany.

Grundt H. H., Popp M., Brochmann C., Oxelman B. (2004) Polypolid origins in a circumpolar complex in Draba (Brassicaceae) inferred from cloned nuclear DNA sequences and fingerprints. Molec. Phylogenet. Evol. 32: 695-710.

Hall J. C., Sytsma K. J., Iltis H. H. (2002) Phylogeny of Capparaceae and Brassicaceae based on chloroplast sequence data. Amer. J. Bot. 89: 1826-1842.

Hauser L. A., Crovello T. J. (1982) Numerical analysis of generic relationships in Thelypodieae (Brassicaceae). Syst. Bot. 7: 249-268.

Hayek A. (1911) Entwurf eines Cruciferensystems auf phylogenetischer Grundlage. Beih. Bot. Centralbl. 27: 127-335.

Hedge I. C. (1976) A systematic and geographical survey of the Old World Cruciferae. In: MacLeod A. J., Jones B. M. G. (eds.) The biology and chemistry of the Cruciferae. Academic Press, London New York San Francisco, pp. 1-45.

Hedge I. C., Kjaer A., Malver O. (1980) Dipterygium - Cruciferae or Capparaceae? Notes Roy. Bot. Gard. Edinburgh 38: 247-250.

Heenan P. B., Mitchell A. D. (2003) Phylogeny, biogeography and adaptive radiation of Pachycladon (Brassicaceae) in the mountains of South Island, New Zealand. J. Biogeogr. 30: 17371749.

Heenan P. B., Mitchell A. D., Koch M. (2002) Molecular systematics of the New Zealand Pachycladon (Brassicaceae) complex: generic circumscription and relationship to Arabidopsis s.1. and Arabis s.1. New Zealand J. Bot. 40: 543562.

Hewson H. J. (1981) The genus Lepidium L. (Brassicaceae) in Australia. Brunonia 4: 217 308.

Hoisington D., Khairallah M., Reeves T., Ribaut J.-M., Skovmand B., Taba S., Warburton M. (1999) Plant genetic resources: what can they contribute toward increased crop productivity? Proc. Natl. Acad. Sci. 96: 5937-5943.

Hülskamp M. (2000) How plants split hairs. Current Biol. 10: R308-310. 
Jacquemoud F. (1984) Etude du genre Anchonium DC. (Cruciferae). Candollea 39: 715-769.

Jacquemoud F. (1988) Monographie du genre Strigmostemum M. Bieb. (Cruciferae-Hesperideae). Boissiera 40: 4-161.

Janchen E. (1942) Das System der Cruciferen. Oesterr. Bot. Zeit. 91: 1-18.

Johnston J. S., Pepper A. E., Hall A. E., Chen Z. J., Hodnett G., Drabek J., Lopez R., Price H. J. (2005) Evolution of genome size in Brassicaceae. Ann. Bot. 95: 229-235.

Kellogg E. A., Bennetzen J. L. (2004) The evolution of nuclear genome structure in seed plants. Amer. J. Bot. 91: 1709-1725.

Kers L. E. (2003) Capparaceae. In: Kubitzki K., Bayer C. (eds.) The families and genera of vascular plants, Springer, Berlin, pp. 36-36.

Koch M. (2002) Genetic differentiation and speciation in prealpine Cochlearia: Allohexaploid Cochlearia bavarica Vogt (Brassicaceae) compared to its diploid ancestor Cochlearia pyrenaica DC. in Germany and Austria. Pl. Syst. Evol. 232: 35-49.

Koch M. (2003) Molecular phylogenetics, evolution and population biology in Brassicaceae. In: Sharma A.K., Sharma A. (eds.) Plant genome: biodiversity and evolution, vol. 1a (phanerogams). Science Publishers, Enfield, NH, USA, pp. 1-35.

Koch M., Al-Shehbaz I. A. (2000) Molecular systematics of the Chinese Yinshania (Brassicaceae): Evidence from plastid and nuclear ITS DNA sequence data. Ann. Missouri Bot. Gard. 87: 246-272.

Koch M., Al-Shehbaz I. A. (2002) Molecular data indicate complex intra- and intercontinental differentiation of American Draba (Brassicaceae). Ann. Missouri Bot. Gard. 89: 88-109.

Koch M., Al-Shehbaz I. A. (2004) Taxonomic and phylogenetic evaluation of the American "Thlas$p i$ " Species: identity and relationship to the Eurasian genus Noccaea (Brassicaceae). Syst. Bot. 29: 375-384.

Koch M., Bernhardt K. G. (2004) Comparative biogeography of the cytotypes of annual Microthlaspi perfoliatum (Brassicaceae) in Europe using isozymes and cpDNA data: Refugia, diversity centers, and postglacial colonization. Amer. J. Bot. 91:114-124.

Koch M., Hurka H. (1999) Isozyme analysis in the polyploid complex Microthlaspi perfoliatum (L.)
F. K. Meyer: morphology, biogeography and evolutionary history. Flora 194: 33-48.

Koch M., Mummenhoff K. (2001) Thlaspi s.str. (Brassicaceae) versus Thlaspi s.l.: morphological and anatomical characters in the light of ITS nrDNA sequence data. Pl. Syst. Evol. 227: 209225.

Koch M., Hurka H., Mummenhoff K. (1996) Chloroplast DNA restriction site variation and RAPD-analyses in Cochlearia (Brassicaceae): biosystematics and speciation. Nord. J. Bot. 16: 585-603.

Koch M., Huthmann M., Hurka H. (1998) Molecular biogeography and evolution of the Microthlaspi perfoliatum s.l. polyploid complex (Brassicaceae): chloroplast DNA and nuclear ribosomal DNA restriction site variation. Canad. J. Bot. 76: 382-396.

Koch M., Bishop J., Mitchell-Olds T. (1999a) Molecular systematics of Arabidopsis and Arabis. Pl. Biol. 1: 529-537.

Koch M., Mummenhoff K., Hurka H. (1999b) Molecular phylogenetics of Cochlearia (Brassicaceae) and allied genera based on nuclear ribosomal ITS DNA sequence analysis contradict traditional concepts of their evolutionary relationship. Pl. Syst. Evol. 216: 207-230.

Koch M., Haubold B., Mitchell-Olds T. (2000) Comparative evolutionary analysis of chalcone synthase and alcohol dehydrogenase loci in Arabidopsis, Arabis, and related genera (Brassicaceae). Molec. Biol. Evol. 17: 1483-1498.

Koch M., Haubold B., Mitchell-Olds T. (2001) Molecular systematics of the Brassicaceae: evidence from coding plastidic mat $\mathrm{K}$ and nuclear Chs sequences. Amer. J. Bot. 88: 534-544.

Koch M., Al-Shehbaz I. A., Mummenhoff K. (2003a) Molecular systematics, evolution, and population biology in the mustard family (Brassicaceae). Ann. Missouri Bot. Gard. 90: 151-171.

Koch M., Bernhardt K. G., Kochjarová J. (2003b) Cochlearia macrorrhiza (Brassicaceae): a bridging species between Cochlearia taxa from the Eastern Alps and the Carpathians. Pl. Syst. Evol. 242: 137-147.

Koch M., Dobeš C., Mitchell-Olds T. (2003c) Multiple hybrid formation in natural populations: concerted evolution of the internal transcribed spacer of nuclear ribosomal DNA (ITS) in North American Arabis divaricarpa (Brassicaceae). Molec. Biol. Evol. 20: 338-350. 
Kropf M. (2002) Vergleichende Biogeographie europäischer Gebirgspflanzen: Molekulare und morphometische Untersuchungen an der montan-sulalpinen Anthyllis montana L. (Fabaceae) und der hochalpinen Pritzelago alpina (L.) Kuntze (Brassicaceae). Doctorate Dissertation, Mainz University. Cuvillier, Göttingen.

Lagercrantz U. (1998) Comparative mapping between Arabidopsis thaliana and Brassica nigra indicate the Brassica genomes have evolved through extensive genome replication accompanied by chromosome fusions and frequent rearrangements. Genetics 150: 1217-1228.

Lagercrantz U., Lydiate D. (1996) Comparative genome mapping in Brassica. Genetics 144: 1903-1910.

Lee J.-Y., Mummenhoff K., Bowman J. L. (2002) Allopolyploidization and evolution of species with reduced floral structures in Lepidium L. (Brassicaceae). Proc. Natl. Acad. Sci. U.S.A. 99: 16835-16840.

Les D. H. (1994) Molecular systematics and taxonomy of the lake cress (Neobeckia aquatica; Brassicaceae), an imperiled aquatic mustard. Aquat. Bot. 49: 149-165.

Lihová J., Marhold K., Neuffer B. (2000) Taxonomy of Cardamine amara (Cruciferae) in the Iberian Peninsula. Taxon 49: 747-763.

Liljegren S. J., Ditta G. S., Eshed Y., Savidge B., Bowman J. L., Yanofsky M. F. (2000) SHATTERPROOF MADS-box genes control seed dispersal in Arabidopsis. Nature 404: 766-770.

Liljegren S. J., Roeder A. H. K., Kempin S. A., Gremski K., Ostergaard L., Guimil S., Reyes D. K., Yanofsky M. F. (2004) Control of fruit patterning in Arabidopsis by INDEHISCENT. Cell 116: 843-853.

Lysak M. L., Koch M. A., Pecinka A., Schubert I. (2005) Chromosome triplication found across the tribe Brassiceae. Genome Res. 15: 516-525.

Lysak M., Lexer C. (2006) Towards the era of comparative evolutionary genomics in Brassicaceae. Pl. Syst. Evol. 259: 175-198.

Marais W. (1966) Cruciferae. In: Codd L. E., Winter B. D., Killick D. J. B., Rycroft H. B. (eds.) Flora of Southern Africa, Vol. 13. Government Printer, Pretoria, pp. 1-118.

Marhold K., Huthmann M., Hurka H. (2002a) Evolutionary history of the polyploid complex of
Cardamine amara (Brassicaceae): isozyme evidence. Pl. Syst. Evol. 233: 15-28.

Marhold K., Lihová J. (2006) Polyploidy, hybridization and reticulate evolution: lessons from the Brassicaceae. Pl. Syst. Evol. 259: 143-174.

Marhold K., Lihová J., Perny M., Grupe R., Neuffer B. (2002b) Natural hybridization in Cardamine (Brassicaceae) in the Pyrenees: evidence from morphological and molecular data. Bot. J. Linn. Soc. 139: 275-294.

Marhold K., Lihová J., Perny M., Bleeker W. (2004) Comparative ITS and AFLP analysis of diploid Cardamine (Brassicaceae) taxa from closely related polyploid complexes. Ann. Bot. 93: 507-520.

Meyer F. K. (1973) Conspectus der "Thlaspi"Arten Europas, Afrikas und Vorderasiens. Feddes Repert. 84: 449-470.

Meyer F. K. (1979) Kritische Revision der "Thlaspi"-Arten Europas, Afrikas und Vorderasiens. I. Geschichte, Morphologie und Chorologie. Feddes Repert. 90: 129-154.

Meyer F. K. (2001) Kritische Revision der "Thlaspi"-Arten Europas, Afrikas und Vorderasiens, Spezieller Tiel, I. Thlaspi L. Haussknechtia 8: 342.

Mitchell A. D., Heenan P. B. (2000) Systematic relationships of New Zealand endemic Brassicaceae inferred from nrDNA ITS sequence data. Syst. Bot. 25: 98-105.

Mitchell-Olds T., Al-Shehbaz I. A., Koch M., Sharbel T. F. (2005) Crucifer evolution in the post-genomic era. In: Henry R. J. (ed.) Plant diversity and evolution: genotypic and phenotypic variation in higher plants. CAB International, pp. 119-137.

Mulligan G. A. (1996) Synopsis of the genus Arabis (Brassicaceae) in Canada, Alaska and Greenland. Rhodora 97: 109-163.

Mummenhoff K. (1995) Should Cardaria draba (L.) Desv. be classified within the genus Lepidium L. (Brassicaceae)? Evidence from subunit polypeptide composition of RUBISCO. Feddes Repert. 106: 25-28.

Mummenhoff K., Hurka H. (1994) Subunit polypeptide composition of rubisco and the origin of allopolyploid Arabidopsis suecica (Brassicaceae). Biochem. Syst. Ecol. 22: 807-812.

Mummenhoff K., Hurka H. (1995) Allopolyploid origin of Arabidopsis suecica (Fries) Norrlin - 
evidence from chloroplast and nuclear genome markers. Bot. Acta 108: 449-456.

Mummenhoff K., Koch M. (1994) Chloroplast DNA restriction site variation and phylogenetic relationships in the genus Thlaspi sensu lato Brassicaceae. Syst. Bot. 19: 73-88.

Mummenhoff K., Franzke A., Koch M. (1997a) Molecular data reveal convergence in fruit characters used in the classification of Thlaspi s.l. (Brassicaceae). Bot. J. Linn. Soc. 125: 183-199.

Mummenhoff K., Franzke A., Koch M. (1997b) Molecular phylogenetics of Thlaspi s.l. (Brassicaceae) based on chloroplast DNA restriction site variation and sequences of the internal transcribed spacers of nuclear ribosomal DNA. Canad. J. Bot. 75: 469-482.

Mummenhoff K., Brüggemann H., Bowman J. L. (2001a) Chloroplast DNA phylogeny and biogeography of Lepidium (Brassicaceae). Amer. J. Bot. 88: 2051-2063.

Mummenhoff K., Coja U., Brüggemann H. (2001b) Pachyphragma and Gagria (Brassicaceae) revisited: molecular data indicate close relationship to Thlaspi s.str. Folia Geobot. 36: 293-302.

Mummenhoff K., Linder P., Friesen N., Bowman J. L., Lee J. Y., Franzke A. (2004) Molecular evidence for bicontinental hybridogenous genome constitution in Lepidium sensu stricto (Brassicaceae) species from Australia and New Zealand. Amer. J. Bot. 91: 254-261.

Mummenhoff K., Al-Shehbaz I. A., Bakker F. T., Linder H. P., Mühlhaussen A. (2005) Phylogeny, morphological evolution, and speciation of endemic Brassicaceae genera in the Cape flora of southern Africa. Ann. Missouri Bot. Gard. 92: $400-424$.

Neuffer B., Janche P. (1997) RAPD analysis of hybridization events in Cardamine (Brassicaceae). Folia Geobot. Phytotax. 32: 57-67.

Nutt P., Ziermann J., Hintz M., Neuffer B., Theisen G. (2006) Capsella as a model system to study the evolutionary relevance of floral homeotic mutants. Pl. Syst. Evol. 259: 217-235.

Nuttall T. (1834) A description of some of the races or little known plants indigenous to the United States, from the dried specimens in the herbarium of the Academy of Natural Sciences in Philadelphia. J. Acad. Nat. Sci. Philad. 85: 61-85.

O'Kane S. L. Jr., Al-Shehbaz I. A. (1997) A synopsis of Arabidopsis (Brassicaceae). Novon 7: 323-327.
O'Kane S. L. Jr., Al-Shehbaz I. A. (2003) Phylogenetic position and generic limits of Arabidopsis (Brassicaceae) based on sequences of nuclear ribosomal DNA. Ann. Missouri Bot. Gard. 90: 603-612.

O'Kane S. L., Jr., Al-Shehbaz I. A. (2004) The genus Physaria (Brassicaceae) in South America. Novon 14: 198-207.

O'Kane S. L. Jr., Schaal B. A., Al-Shehbaz I. A. (1997) The origins of Arabidopsis suecica (Brassicaceae) as indicated by nuclear rDNA sequences. Syst. Bot. 21: 559-566.

Polster A. (2005) The role of lignification patterns in dehiscent and indehiscent fruits in Brassicaceae: a comparative anatomical approach. M.Sc. thesis, Department of Biology/Chemistry. University of Osnabrück, Germany.

Prantl K. (1891) Cruciferae. In: Engler A., Prantl K. (eds.) Die natürlichen Pflanzenfamilien III. Verlag von Wilhelm Engelmann, Leipzig, pp. 145-206.

Price R. A., Palmer J. D., Al-Shehbaz I. A. (1994) Systematic relationships of Arabidopsis: a molecular and morphological approach. In: Meyerowitz E., Somerville C. (eds.) Arabidopsis. Cold Spring Harbor Press, Cold Spring Harbor, NY, pp. 7-19.

Price R. A., Al-Shehbaz I. A., O'Kane S. L. Jr. (2001) Beringia (Brassicaceae), a new genus of Arabidopsoid affinities from Russia and North America. Novon 11: 332-336.

Robinson B. L. (1895) Cruciferae. In: Gray A., Watson S. (eds.) Synoptical flora of North America. vol. 1, part 1. American Book Company, New York Cincinnati Chicago, pp. 98105.

Rollins R. C. (1941) A monographic study of Arabis in western North America. Rhodora 43: 289-325, 348-411, 425-485.

Rollins R. C. (1979) Dithyrea and a related genus (Cruciferae). Publ. Bussey Inst. Harvard Univ. 1979: 3-20.

Rollins R. C. (1983) Interspecific hybridization and taxon uniformity in Arabis (Cruciferae). Amer. J. Bot. 70: 625-634.

Rollins R. C. (1984) Sphaerocardamum (Cruciferae). Contr. Gray Herb. 213: 11-17.

Rollins R. C. (1993) The Cruciferae of Continental North America, Stanford University Press, Stanford. 
Rollins R. C., Banerjee U. C. (1975) Atlas of the trichomes of Lesquerella (Cruciferae). Publ. Bussey Inst. Harvard Univ. 1975: 1-48.

Rollins R. C., Banerjee U. C. (1976) Trichomes in studies of the Cruciferae. In: Vaughan J. G., MacLeod A. J., Jones B. M. G. (eds.) The biology and chemistry of the Cruciferae. Academic Press, London New York San Francisco, pp. 145-166.

Rollins R. C., Banerjee U. C. (1979) Pollen of the Cruciferae. Publ. Bussey Inst. Harvard Univ. 1979: 33-64.

Roy B. A. (1995) The breeding systems of six species of Arabis (Brassicaceae). Amer. J. Bot. 82: 869-877.

Roy B. A. (2001) Patterns of association between crucifers and their flower-mimic pathogens: Host jumps are more common than coevolution or cospeciation. Evolution 55: 41-53.

Scheen A.-C., Elven R., Brochmann C. (2002) A molecular-morphological approach solves taxonomic controversy in arctic Draba (Brassicaceae). Canad. J. Bot. 80: 59-71.

Schranz M., Mitchell-Olds T. (2005) Independent polyploidy events in the sister families Brassicaceae and Capparaceae. XVII International Botanical Congress-Abstract 1.6.7. Vienna.

Schulz O. E. (1919) Cruciferae-Brassiceae. Part 1. In: Engler A. (ed.) Pflanzenreich IV. 105 (Heft 70). Verlag von Wilhelm Engelmann, Leipzig, pp. 1-290.

Schulz O. E. (1923) Cruciferae-Brassiceae. Part 2. In: Engler A. (ed.) Pflanzenreich IV. 105 (Heft 84). Verlag von Wilhelm Engelmann, Leipzig, pp. 1-100.

Schulz O. E. (1924) Cruciferae-Sisymbrieae. In: Engler A. (ed.) Pflanzenreich IV. 105(Heft 86). Verlag von Wilhelm Engelmann, Leipzig, pp. 1388.

Schulz O. E. (1936) Cruciferae. In: Engler A., Harms H. (eds.) Die natürlichen Pflanzenfamilien, vol. 17B. Verlag von Wilhelm Engelmann, Leipzig, pp. 227-658.

Schwab B., Folkers U., Ilgenfritz H., Hülskamp M. (2000) Trichome morphogenesis in Arabidopsis. Phil. Trans. Roy. Soc. London, Biol. Sci. 355: 879-883.

Sharbel T. F., Mitchell-Olds T. (2001) Recurrent polyploid origins and chloroplast phylogeography in the Arabis holboellii complex (Brassicaceae). Heredity 87: 59-68.
Sharbel T. F., Voigt M.-L., Mitchell-Olds T., Kantama L., de Jong H. (2004) Is the aneuploid chromosome in an apomictic Boechera holboellii a genuine B chromosome? Cytogenet. Genome Res. 106: 173-183.

Shaw E. (1972) A revision of Stenopetalum (Cruciferae). J. Arnold Arbor. 53: 52-75.

Shu G., Amaral W., Hileman L. C., Baum D. A. (2000) LEAFY and the evolution of rosette flowering in violet cress (Ionopsidium acaule, Brassicaceae). Amer. J. Bot. 87: 634-641.

Sweeney P. W., Price R. A. (2000) Polyphyly of the genus Dentaria (Brassicaceae): evidence from $t r n \mathrm{~L}$ intron and $n d h \mathrm{~F}$ sequence data. Syst. Bot. 25: 468-478.

Szymanski D., Lloyd A. M., Marks M. D. (2000) Progress in the molecular genetic analysis of trichome initiation and morphogenesis in $\mathrm{Ara}$ bidopsis. Trends Pl. Sci. 5: 214-219.

Takhtajan A. (1997) Diversity and classification of flowering plants. Columbia University Press, New York.

Tan K. (2002) Arabis. In: Strid A., Tan K. (eds.) Fl. Helenica, vol. 2. Koeltz Scientific Books, Königstein, Germany, pp. 184-192.

The Arabidopsis Genome Initiative (2000) Analysis of the genome sequence of the flowering plant Arabidopsis thaliana. Nature 408: 796-815.

Urbanska K. M., Hurka H., Landolt E., Neuffer B., Mummenhoff K. (1997) Hybridization and evolution in Cardamine (Brassicaceae) at Urnerboden, central Switzerland - biosystematic and molecular evidence. Pl. Syst. Evol. 204: 233-256.

van Dijk P., van Damme J. (2000) Apomixis technology and the paradox of sex. Trends Pl. Sci. 5: 81-84.

Warwick S. I., Al-Shehbaz I. A. (1998) Generic evaluation of Boleum, Euzomodendron, and Vella (Brassicaceae). Novon 8: 321-325.

Warwick S. I., Al-Shehbaz I. A. (2003) Nomenclatural notes on Sisymbrium (Brassicaceae). Novon 13: 265-267.

Warwick S. I., Al-Shehbaz I.A. (2006) Brassicaceae: Chromosome number index. Pl. Syst. Evol. 259: 237-248.

Warwick S. I., Black L. D. (1994) Evaluation of the subtribes Moricandiinae, Savignyinae, Vellinae, and Zillinae (Brassicaceae, Tribe Brassiceae) using chloroplast DNA restriction site variation. Canad. J. Bot. 72: 1692-1701. 
Warwick S. I., Black L. D. (1997a) Molecular phylogenies from theory to application in Brassica and allies (Tribe Brassiceae, Brassicaceae). Opera Bot. 132: 159-168.

Warwick S. I., Black L. D. (1997b) Phylogenetic implications of chloroplast DNA restriction site variation in subtribes Raphaninae and Cakilinae (Brassicaceae, tribe Brassiceae). Canad. J. Bot. 75: 960-973.

Warwick S. I., Sauder C. (2005) Phylogeny of tribe Brassiceae (Brassicaceae) based on chloroplast restriction site polymorphisms and nuclear ribosomal internal transcribed spacer and chloroplast $t r n \mathrm{~L}$ intron sequences. Canad. J. Bot. 83: 467-483.

Warwick S. I., Al-Shehbaz I. A., Price R. A., Sauder C. (2002) Phylogeny of Sisymbrium (Brassicaceae) based on ITS sequences of nuclear ribosomal DNA. Canad. J. Bot. 80: 1002-1017.

Warwick S. I., Al-Shehbaz I. A., Sauder C., Harris J. G., Koch M. (2004a) Phylogeny of Braya and Neotorularia (Brassicaceae) based on nuclear ribosomal internal transcribed spacer and chloroplast $t r n \mathrm{~L}$ intron sequences. Canad. J. Bot. 82: 376-392.

Warwick S. I., Al-Shehbaz I. A., Sauder C., Murray D. F., Mummenhoff K. (2004b) Phylogeny of Smelowskia and related genera (Brassicaceae) based on nuclear ITS DNA and chloroplast $\operatorname{trn} \mathrm{L}$ intron sequences. Ann. Missouri Bot. Garden 91: 99-123.

Warwick S. I., Al-Shehbaz I. A., Sauder C. (2005a) Phylogeny and cytological diversity of Sisymbrium (Brassicaceae). In: Sharma A. K., Sharma A. (eds.) Plant genome: biodiversity and evolution. Vol. 1C: Phanerogams (Angiosperm - Dicotyledons). Science Publishers, Enfield, NH, USA (in press).

Warwick S. I., Al-Shehbaz I. A., Sauder C. (2005b) Phylogenetic position of Arabis arenicola and generic limits of Eutrema and Aphragmus (Brassicaceae) based on sequences of nuclear ribosomal DNA. Canad. J. Bot. (in press).

Warwick S. I., Francis A., Al-Shehbaz I. A. (2006) Brassicaceae: species checklist. Pl. Syst. Evol. 259: 249-258.
Widmer A., Baltisberger M. (1999a) Molecular evidence for allopolyploid speciation and a single origin of the narrow endemic Draba ladina (Brassicaceae). Amer. J. Bot. 86: 1282-1289.

Widmer A., Baltisberger M. (1999b) Extensive intraspecific chloroplast DNA (cpDNA) variation in the alpine Draba aizoides L. (Brassicaceae): haplotype relationships and population structure. Molec. Ecol. 8: 1405-1415.

Windham M. D., Al-Shehbaz I. A., Bailey C. D., Allphin L. (2004) A taxonomist's worst nightmare: a preliminary glimpse into the systematics of Boechera (Brassicaceae). Amer. J. Bot. 2004 Abstracts: 149.

Yoon H. S., Baum D. A. (2004) Transgenic study of parallelism in plant morphological evolution. Proc. Natl. Acad. Sci. USA 101: 6524-6529.

Yue J. P., Sun H., Al-Shehbaz I. A., Li J. H. (2005) Support for an expanded Solms-laubachia (Brassicaceae): evidence from sequences of chloroplast and nuclear genes. Ann. Missouri Bot. Gard. (in press).

Zhou T. Y., Lu L. L., Yang G., Al-Shehbaz I. A. (2001) Brassicaceae. In: Wu Z. Y., Raven P. H. (eds.) Flora of China. 8: 1-193. Science Press (Beijing) and Missouri Botanical Garden (St. Louis).

Zunk K., Mummenhoff K., Koch M., Hurka H. (1996) Phylogenetic relationships of Thlaspi s.l. (subtribe Thlaspidinae, Lepidieae) and allied genera based on chloroplast DNA restrictionsite variation. Theor. Appl. Genet. 92: 375-381

Zunk K., Mummenhoff K., Hurka H. (1999) Phylogenetic relationships in tribe Lepidieae (Brassicaceae) based on chloroplast DNA restriction site variation. Canad. J. Bot. 77: 1504-1512.

Addresses of the authors: Ihsan A. Al-Shehbaz (e-mail: Ihsan.al-shehbaz@mobot.org) Missouri Botanical Garden, P.O. Box 299, St. Louis, Missouri, USA. Mark A. Beilstein and Elizabeth A. Kellogg, Department of Biology, University of Missouri-St. Louis, 1 University Boulevard, St. Louis, Missouri, USA. 